\title{
Geographies of Postsecularity
}

This book explores the hopeful possibility that emerging geographies of postsecularity are able to contribute significantly to the understanding of how common life may be shared, and how caring for the common goods of social justice, well-being, equality, solidarity, and respect for difference may be imagined and practiced. Drawing on recent geographic theory to recalibrate ideas of the postsecular public sphere, the authors develop the case for postsecularity as a condition of being that is characterised by practices of receptive generosity, rapprochement between religious and secular ethics, and a hopeful re-enchantment and re-shaping of desire towards common life. The authors highlight the contested formation of ethical subjectivity under neoliberalism and the emergence of postsecularity within this process as an ethically-attuned politics which changes relations between religion and secularity, and animates novel, hopeful imaginations, subjectivities, and praxes as alternatives to neoliberal norms. The spaces and subjectivities of emergent postsecularity are examined through a series of innovative case studies, including food banks, drug and alcohol treatment, refugee humanitarian activism in Calais, homeless participatory art projects, community responses to the Christchurch earthquakes in New Zealand, amongst others. The book also traces the global conditions for postsecularity beyond the Western and predominantly Christian-secular nexus of engagement.

This is a valuable resource for students in several academic disciplines, including geography, sociology, politics, religious studies, international development, and anthropology. It will be of great interest to secular and faith-based practitioners working in religion, spirituality, politics or more widely in public policy, urban planning, and community development.

Paul Cloke is Professor of Human Geography at the University of Exeter. He has longstanding research interests in the geographies of social marginalisation and exclusion, and in the political and ethical responses from Third Sector organisations to issues of social care and justice. His recent books include Swept Up Lives (with J May and S Johnsen; Wiley-Blackwell 2010); FBOs and Exclusion in European Cities (with J Beaumont; Policy Press 2012); and Working Faith (with J Beaumont and A Williams; Paternoster 2013).

Christopher Baker is William Temple Professor of Religion and Public Life at Goldsmiths, University of London, where he co-directs the Faiths and Civil Society Unit. His publications engage theology and religious studies with sociology, sociology of religion, human geography, planning, and policy studies. His edited volume Postsecular Cities: Space, Theory and Practice (with J. Beaumont; Continuum 2011) is a much-cited and authoritative text in this field.

Callum Sutherland is a Human Geographer based at the University of Exeter. His published work examines themes of religion, politics, and spiritual activism, with particular regard to Christian praxis and social justice.

Andrew Williams is Lecturer in Human Geography, Cardiff University, and specialises in questions of ethics, welfare, and politics. His latest books include Working Faith: Faith-Based Organisations and Urban Social Justice (with P Cloke and J Beaumont; Paternoster 2013) and Feeding Austerity? Ethical Ambiguity and Political Possibilities in UK Foodbanks (with L Cherry, P Cloke, and J May; Wiley-Blackwell, forthcoming). 


\section{Routledge Research in Place, Space and Politics \\ Series Editor: Professor Clive Barnett \\ University of Exeter, UK}

This series offers a forum for original and innovative research that explores the changing geographies of political life. The series engages with a series of key debates about innovative political forms and addresses key concepts of political analysis such as scale, territory and public space. It brings into focus emerging interdisciplinary conversations about the spaces through which power is exercised, legitimised, and contested. Titles within the series range from empirical investigations to theoretical engagements and authors comprise of scholars working in overlapping fields including political geography, political theory, development studies, political sociology, international relations, and urban politics.

\section{Un-making Environmental Activism}

Beyond Modern/Colonial Binaries in the GMO Controversy

Doerthe Rosenow

\section{The Challenges of Democracy in the War on Terror}

The Liberal State before the Advance of Terrorism

Maximiliano E. Korstanje

\section{The Politics of Settler Colonial Spaces}

Forging Indigenous Places in Intertwined Worlds

Edited by Nicole Gombay and Marcela Palomino-Schalscha

\section{Direction and Socio-spatial Theory}

A Political Economy of Oriented Practice

Matthew G. Hannah

\section{Geographies of Postsecularity}

Re-envisioning Politics, Subjectivity and Ethics

Paul Cloke, Christopher Baker, Callum Sutherland and Andrew Williams

For more information about this series, please visit: www.routledge.com/series/ PSP 


\section{Geographies of Postsecularity Re-envisioning Politics, Subjectivity and Ethics}

\section{Paul Cloke, Christopher Baker, \\ Callum Sutherland and Andrew Williams}

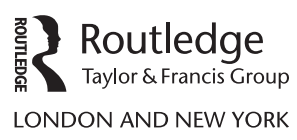


First published 2019

by Routledge

2 Park Square, Milton Park, Abingdon, Oxon OX14 4RN

and by Routledge

52 Vanderbilt Avenue, New York, NY 10017

Routledge is an imprint of the Taylor \& Francis Group, an informa business

(C) 2019 Paul Cloke, Christopher Baker, Callum Sutherland and Andrew Williams

The right of Paul Cloke, Christopher Baker, Callum Sutherland and Andrew Williams to be identified as authors of this work has been asserted by them in accordance with sections 77 and 78 of the Copyright, Designs and Patents Act 1988.

All rights reserved. No part of this book may be reprinted or reproduced or utilised in any form or by any electronic, mechanical, or other means, now known or hereafter invented, including photocopying and recording, or in any information storage or retrieval system, without permission in writing from the publishers.

Trademark notice: Product or corporate names may be trademarks or registered trademarks, and are used only for identification and explanation without intent to infringe.

British Library Cataloguing-in-Publication Data

A catalogue record for this book is available from the British Library

Library of Congress Cataloging-in-Publication Data

A catalog record has been requested for this book

ISBN: 978-1-138-94673-6 (hbk)

ISBN: 978-1-315-67061-4 (ebk)

Typeset in Times New Roman

by Wearset Ltd, Boldon, Tyne and Wear 


\section{Contents}

1 Introduction 1

2 Genealogies 26

3 Subjectivities $\quad 53$

$\begin{array}{llr}4 & \text { Spaces } & 89\end{array}$

5 Political practices $\quad 124$

6 Wider religious and spatial conditions 155

$\begin{array}{llr}7 & \text { Conclusion } & 185\end{array}$

Bibliography 207

Index 235 


\section{Acknowledgements}

The authors would like to express their appreciation to Ruth Anderson at Routledge, and the series editor, Clive Barnett, for their encouragement and expertise in helping to bring this manuscript to fruition. We would also like to thank a host of academic friends and colleagues who have participated with us in our journey with ideas about postsecularity. Special thanks here go to: Justin Beaumont, Sean Carter, Richard Gale, Elaine Graham, Derk Harmannij, Julian Holloway, Jo Little, Jon May, Betsy Olson, Mike Pears, and Sam Thomas for their thoughtfulness, engagement, and enthusiasm.

As always, Paul would like to offer his grateful thanks for the wonderful love, encouragement, and support received from his family - Viv, Liz, Will, Chris, Bronnie, Ethan, Evie (and not forgetting Ringo the dog!). Couldn't do this without you! Huge thanks also to close friends and colleagues in Exeter; in particular, Andy and Callum you have added so much to the richness of academic life there over recent years, as well as - alongside Chris - being critically reflexive and hugely supportive partners in this project. I am also really grateful for the friendship and the close-knit musical community of the Week Four Band at Exeter Vineyard Church, and the Nameless People group at YMCA Exeter. For me, music really has been an antidote to the contemporary conditions of neoliberalised university life!

Chris would like to thank Paul, Andy, and Callum for their critical and supportive approach to the production of this volume. To say to have learnt far more than I feel I have contributed is a huge understatement. Thanks to Dilly, Flossie, and Theo for love, support, and understanding. Thanks to dear friends and colleagues who have shaped my thinking in this work, and whose interdisciplinary approach to religion, belief, politics, and policy has been so influential, as well as a ridiculous amount of fun; especially Elaine Graham, Maria Power, Adam Dinham, Beth Crisp, and John Reader. The work and ethos of the William Temple Foundation continues to inspire and challenge, so huge thanks to the WT family, but especially Professor Canon John Atherton (1939-2016) who set me on the road along which I now travel.

Callum would like to thank Terri, Rich, Rach, Euan, Miggy, Andrew, Hannah, Falky, R.R., A.M., M.C., everyone who helped with my PhD research, the Normans, everyone who has passed through Room 385 (particularly Sue and 
Paula), Anna, Liz, Bronwyn, James, Dad, and my dear co-authors for their sustaining love and guidance and for improving - both directly and indirectly - my contributions to this book.

Andrew would like to thank all his friends and colleagues at Cardiff University, especially the $\mathrm{PhD}$ community who have been a vital source of encouragement along the way. A vast number of people have helped this book to completion, but you will understand that thanking all by name risks inadvertent omissions. To keep this short, I am hugely grateful for Paul, Callum, and Chris your friendship and wisdom has been invaluable in this project. Special thanks also must go to Andy, Noona, Dan, Helen, Tara, Diana, Rich, Bobby, Mark, Dave, Bex, Matt, Gemma, Ant, Mara, Kieran, Jen, Lyndsey, Jack, Neil, Agatha, Julian, Geoff, Gary, Brian, Günter, Evelyn, Emma, and Lucy - who, in different ways, and at key times, have supported me through the writing process. Finally, I am thankful for my parents - John and Lynda - and my family - Paul, Ellie, Jake, and Iris; Stephen, Nicki, Myla, and Kaira; and the Wisby clan in Swansea, Birmingham and Cardiff. Your love and encouragement have helped see me through. 



\section{Introduction}

\subsection{An approach to postsecularity}

This is a book about the hopeful possibility that emerging geographies of postsecularity are able to contribute significantly to the understanding of how common life may be shared, and how caring for the common goods of social justice, well-being, equality, solidarity, and respect for difference may be imagined and practiced. Although the religious and the secular are often defined as binary opposites, our discussion in the book explores alternative configurations of these terms. We regard religion to be conditions of being and cultural systems of belief and faith-practice that seek imperfectly to interconnect humanity with the spiritual and the transcendental. We regard the secular as a political project to deny religion a place in the affairs of state; an imperfect social structure designed to limit conflict by privileging universal human rights above any religious demands. In these terms, then, religion is nether cancelled out, nor taken over by an increasingly secularised society. Rather, over time the religious and the secular are becoming co-assembled in interesting new ways.

Over recent years, the notion of postsecularity has emerged across the humanities and social sciences both as a description of the social, cultural, and political re-emergence or new visibility of religion in the urban public sphere (Beaumont and Baker 2011), and as an analytical frame through which to re-examine the coproduction of religious and secular domains in ways that depart from the secularisation thesis (see Olson et al. 2013). Drawing on formative ideas from Jurgen Habermas and Klaus Eder, the concept of postsecularity reflects both instances of a vigorous continuation of religion in a continually secularising environment, and a more general rise in public consciousness of religious discourse and social action. Despite evidence of a continuing linear movement from 'the relatively religious to the rather secular' (Woodhead 2012, 374), it is now clear that religious identification, belief, and practice continue to be influential, albeit in Western nations often in a more vicarious form involving believing but not belonging (Davie 2015). Contemporary religion, then, concerns myriad and increasingly pluralised sites of subjective and subaltern cultural reproduction as well as more traditional institutions. Rather than focussing on supposed moves from the religious to the secular or vice versa, we seek to shift the emphasis of 


\section{Introduction}

these debates towards the particular sites, spaces, and practices where diverse religious, humanist, and secular voices come together dialogically and enter into a learning and experimental process in which secular and religious mentalities can be reflexively transformed.

Previously the secularisation thesis (Berger 1967) had suggested the gradual demise of religion as a relevant discourse in the public arena. Habermas (2010) notes how the differentiation of functional social systems during much of the twentieth century resulted in churches and religious communities withdrawing from much of their wider societal intervention, and increasingly confining themselves to their core duties of pastoral care. At the same time, the practice of personal faith also became more individualised, more associated with private pursuit of ritual and dogma than with agitating for wider social responsibility. However, Habermas points to significant areas of social change that have arrested and even reversed some of these privatising trends. First, given the process of Western transformation into post-colonial immigrant societies, the social integration of immigrant cultures has been at least in part bound up in the question of how to achieve tolerant and hospitable coexistence between different religious communities. Second, there is evidence that cultural and social modernisation does not depend on the necessity of depleting the public and personal relevance of religion. Indeed, as we discuss in Chapter 2, the supposed hopelessness of the current post-political age rests in no small measure on a disillusionment about the capacity of the economics, science, technology, and ethics of the neoliberalised secular age to offer any solutions to fundamental issues of inequality, injustice, and commodity fetishism. Third, and partly in the form of a response to these circumstances, Habermas notes that religion has begun to regain influence in a variety of public spheres, most notably as churches and faith-based organisations increasingly assume a public role of 'communities of interpretation', for example, by using their voice to campaign about key issues of social injustice and to speak truth to power in various ways. Accordingly, the previously hushed-up voice of religion is, according to Eder (2006), beginning to be heard again in the public sphere, a turnaround reflected in Berger's (1999) recognition of the counter-secularising forces manifest in desecularisation, and in Casanova's (2011) modifications to the secularisation thesis, acknowledging that despite multiple and diverse secularisations in the West, and multiple and diverse Western modernities, religion remains relevant and influential despite the onward march of other elements of modernist secularisation.

You may well ask, so what? Given a broad presumption amongst the largely secularised academy of social science that religion (typically illustrated by extreme fundamentalist practices) is either an irrelevant cluster of myths and rituals, or indeed a negative source of illiberal attitudes towards violence and social and cultural alterity, the only cause for concern might be that the secularisation of society has not completed the task of privatising religion and stripping it of its public voice. We want to acknowledge at this early stage that some partnerships between the religious and the secular clearly do have a 'dark side' that becomes apparent when strongly conservative religious and political discourses 
combine to construct political and ethical battlegrounds from which to oppose human rights in areas, for example, relating to sexuality, gender, and welfare (see, for example, Valentine and Waite 2011). Such instances, although appearing to fulfil the criteria of 'postsecular', contribute nothing of value to the inculcation of more hopeful geographies, and merely serve to reinforce a characterisation of religion as being hand-in-glove with neoliberal politics of subject-formation (see, for example, Hackworth 2012), and with a more general politics of disgust (see Inbar et al. 2009).

However, in this book we present a rather different, and (in our view) more progressive notion of postsecularity, and as a start, for clarity of argument, we need to be clear what we think postsecularity is not: not a universal epochal shift; not a wholesale regime change of entire cities or nations; not a reversal of secularisation; not a return to some kind of pre-secular; not a campaign that equates religion with illiberal moralities. All of these notions appear to us to be too hefty, blunt, and binaric (see Dwyer 2016) to be useful. Rather we envisage postsecularity as a more context-contingent bubbling up of ethical values arising from amalgams of faith-related and secular determination to relate differently to alterity and become active in support of others by going beyond the social bubble of the normal habitus. These ethical values are marked by an explicit 'crossing-over' of religious and secular narratives, practices, and performances that become visible in key geographical expressions of overcoming difference; in certain spaces devoted to care, welfare, justice, and protest, and in certain expressions of dynamic subjectivity characterised by greater degrees of incommonness and heightened care for the common good. It is for these reasons we place a deliberate emphasis on the concept of postsecularity - as a condition of being - in preference to specific time-space conceptions of the 'postsecular', and their philosophical justifications wrapped up in 'postsecularism'. The being of postsecularity is conditioned by a co-productive relationship between faith and reason, involving a commitment to solidarity and an openness to difference. It is about doing something together based on an acceptance of the unknowns and unknowables in particular contexts and being open to what could emerge from a mutual action based on ethical negotiation. It can reflect to varying extents both a relaxation of secular suspicion towards spirituality and related reenchantment, and a willingness to take religious values out into the secular world without being consumed by the fear that in so doing those values will not be diluted or undermined. In these terms, and as we proceed to examine in later chapters, geographies of postsecularity are evident, and can be comprehended, in normative, empirical, and phenomenological registers, reflecting a blurring of sacred and secular spaces and subjectivities through the co-production of hopeful imaginaries, hopeful ethical sensibilities, and hopeful practices.

\subsection{Contexts of postsecularity}

One of the key distinctions in our approach to postsecularity is that we recognise it to be context-contingent. This not only applies to the geographical diversity of 


\section{Introduction}

religion, and the consequent careful assertion that what we are examining here takes a particular form in affluent areas of Europe, Canada, and Australasia (although also traceable in different forms elsewhere - see Chapter 6), but also to particular periods of political and material change. One of the principal objections to the idea of the postsecular (see, for example, Kong 2010; Ley 2011; Wilford 2010 ) is that it simply describes what is already known to have existed over long historical periods. In one sense, this argument is apparent in our introduction so far; secularisation has patently not killed off religion, neither is religious intervention in the public spaces of wider society a new phenomenon. Prochaska (2008), for example, charts the importance of Christian motivation to philanthropy and the politics of social justice in the UK in the nineteenth century, examining the importance of religious associations and benefactors for the delivery of public services prior to the establishment of the welfare state. Many of the organisations whose roots lay in this period - for example, the Salvation Army - have actively continued their public role over subsequent years and remain part of the landscape of contemporary postsecularity. Equally, religious narratives and organisations are evident in the history of counselling and psychotherapy (Bondi 2013), education (Dwyer and Parutis 2012; Watson 2013) and political activism (Marsh 2003; Smith 1996). We would argue that revisiting these spaces through the gaze of postsecularity has the capacity to reveal a more complex picture of assimilation and mutually reflexive transformation of secular and theological ideas than presented elsewhere. However, we do also want to suggest that the bubbling up of spaces and subjectivities of postsecularity in the present day owes much to the way in which contemporary events are delivering particular phenomenologies of need and of societal change which in turn serve to motivate a desire for collaborative activity. Put simply, the subjective conditions of late-capitalism and latesecularism have fundamentally changed. Ward (2009), for example, identifies globalisation with its attendant multiculturalism and insecure patterns of working life, and postmodernity with its espousal of the ironic, the eclectic, and soft forms of hypersubjectivity, as crucial to the assemblage of new kinds of circumstances, including a reanimated embrace of spirituality.

It is important, then, to acknowledge that the context of postsecularity is changing, and that there are aspects of emergent postsecularity that underscore the significance of the contemporary empirical moment (see Williams 2015). For example, the form and intensity of religious/secular crossovers have changed significantly through the multifarious realisation of radically plural societies (Molendijk et al. 2010). Established sources of secularity and ideologies of secularism have been reconfigured as liberal democratic states enlist diverse religious groups to deliver social cohesion, representation, and 'culturally appropriate' services (Beckford 2012; De Vries 2006). As a result, ethical values are increasingly being constructed through amalgamations of secular, spiritual, and religious frameworks (Bender and Taves 2012). Similar shifts towards postsecularity are also evident in the discourses and practices of international development and humanitarianism (Ager and Ager 2011; Deneulin and Rakodi 2011; Khanum 2012; Mitchell 2017), and in the growth of 'alternative' economic spaces linked 
to Islamic influence in global political-economic networks (Atia 2012; Pollard and Samers 2007). Further evidence of postsecularity can be found in the pluralistic sensibilities and horizontalist organisation of recent social movements - for example, Occupy Wall Street, Taksim Gezi Park and the Arab Spring (see Cloke et al. 2016; Barbato 2012; Dabashi 2012; Mavelli 2012) - all of which have been marked by an explicit 'crossing over' of religious and secular narratives, symbolism, practice, and performance in public space. These trends, events, and circumstances indicate not so much a differentiation of religion from supposedly secular spheres of political, cultural, and economic life (Wilford 2010), but rather how the mutually constitutive dynamics between religious and secular are becoming increasingly visible in the public domain.

Postsecularity in these terms can be represented as an epiphenomenon of its times; an effect of, response to, and resistance against dramatic global and cultural transformations, often illustrated in terms of how poorer communities and societies reach out to religion as a response to the need for reassurance (see, for example, Davis' 2007 account of Planet of Slums). Such illustrations, of course, often serve to reinforce the prejudicial regard for hierarchical forms of religion as an expression of existential insecurity (Norris and Inglehart 2004), but we want to argue that religion - and in particular more non-hierarchical forms of spirituality - can equally be viewed as an intrinsically important and valuable cause of affirmative human activity. For example, the propensity for postsecular collaboration has clearly flourished in the landscape of neoliberal governance, as gaps left by shrinking public service provision and the contracting out of service delivery have been filled at least in part by faith-based and other Third Sector organisations. In a recent discussion of food banking in the UK, Cloke et al. (2017) suggest that current responses to food insecurity and poverty is occurring 'in the meantime' - gesturing both to the meanness of neoliberal politics of austerity that disproportionately penalise the poorest members of society, and to the necessity to take immediate action whilst at the same time mobilising an ethics and politics of social justice in resistance to the causes of this poverty. It is the phenomenology of need, coupled with a latent ethical sensibility to act (often in this case founded on theological as well as ideological properties) that may well be causing a wider conscientisation of staff and volunteers in food banks, and a host of other settings of care and welfare. As the welfare state becomes denuded and hollowed out, so a small multitude of people are being prompted to act because of personal and societal experience of the unmet needs of others. Some commentators translate these context-contingent causes and effects as surrender of religious specificity and incorporation into the political ethos of state-led governmentality. Third Sector involvements in welfare are therefore typically interpreted as being co-opted by and attuned to the objectives and values of contemporary governance. Woodhead $(2012,15)$ gives us one such narrative drawing on recent history when the political left ruled the urban political roost:

Once the churches had thrown in their lot with the welfare state and with secular priorities, however, their distinctiveness was in danger. They became 
part of the social fabric and the reigning moral and cultural ethos. This was one reason why religion became increasingly invisible in the welfare era. Another was that, once the churches had surrendered control to the state, the partnership could easily be forgotten, particularly by the political left.

We acknowledge that negative public response to faith-based organisations seems to have eased over intervening years (Beaumont and Cloke 2012). However, more generally, such analyses seemingly present an interpretative frame that offers an unhelpful choice when analysing religious public action between being understood as co-option or as resistance; and in so doing obscures some of the more progressive possibilities that can arise in and through the spaces of postsecular action. As we discuss in Chapters 3 and 4, many of these spaces of postsecularity may be more fruitfully understood in terms of a theoretical 'messy middle' (May and Cloke 2014) in which obsession with either/or frameworks of understanding makes it is easy to pass over the ordinary but significant ethics and politics of possibility constructed and performed therein both as an effect of the context, and as a cause of context-specific agency.

If specific temporal phases of globalisation and neoliberal austerity offer one set of political landscapes in which to understand context-contingent postsecularity, then another significant form of context is pedagogic in nature. In short, the heavily secularised nature of the social science academy has often resulted in an unwillingness to recognise religion as a force for good, or as a useful partner in secular endeavours. This secular social scientific gaze has resulted in a reluctance to contemplate the possibility of postsecularity at work, which in turn presents a pedagogic stumbling block to the recognition of any potential hopefulness arising in spaces and subjectivities of postsecularity. If a hegemonic pedagogic interpretation of religion only allows us to interpret faith-based activities as self-serving acts of charity, that at best provide an outlet for liberal guilt and morality, and at worst provide cover for proselytising and entrapment of vulnerable citizens, then it follows automatically that no good can come of such activities, and any scholarship that suggests otherwise is simply uncritical. It is only as this blinkered set of assumptions has been challenged that the recognition and critical examination of geographies of postsecularity has been enabled. A brief review of geographies of religion (see, for example, Hopkins et al. 2013) illustrates the rising importance of this challenge. Until very recently, geographical study of religion has been carried out in a marginalised subfield that has struggled to establish itself as mainstream and has been neglected as a source of interdisciplinary or cross-disciplinary initiative (Ley and Tse 2013; Tse 2014). Religion has been the last great otherness in geography; that which has been most shunned and swerved around by the general practice of the subject, which on the whole remains resolutely secular in nature and cautious about conceiving of religion as being interconnected with progressive ethics or politics (see Cloke 2010; 2011). In Yorgason and della Dora's $(2009,629)$ terms, religion has been the 'terra incognita' of human geography. More recently, however, interesting cross-overs between religion and other geographical issues - gender, mobility, 
identity, welfare provision, ethicality, and the like - have prompted a gentle repositioning of scholarship on religion and spirituality (see, for example, Bartolini et al. 2016; Hopkins et al. 2012; Holloway and Valins 2010; Kong 2010; Yorgason and della Dora 2009). As part of this steer - one can hardly think of it as a 'turn' - geographers have become more actively involved in multidisciplinary discussions (sparked initially by the work of Justin Beaumont 2008a; 2008b; Beaumont and Dias 2008) relating to the possibilities of faith-based involvement in wider practices of postsecularity. A series of seminal conferences and edited collections have followed (including Molendijk et al. 2010; Beaumont and Baker 2011; Beaumont and Cloke 2012; Gorski et al. 2012; Nynas et al. 2015) that have served to open up discussion of how geography might respond to and interact with the concept of postsecularity.

One crucial element of these multidisciplinary discussions has been a gradual, and perhaps sometimes grudging, acknowledgement that intellectual appreciation of faith, belief, and religion has needed to change. The starting point in wider social science was similar to that in geography; there were vested interests in the continuing adhesion to the secularisation thesis, not least so as to enable critique of religion as an integral part of the broader Enlightenment agenda. Even those who were responsible for subdisciplines that addressed religion (for example, in sociology and geography) seem to have been reluctant to embrace new ideas about postsecularity, claiming that there was nothing new in such ideas, and that they amounted to a red herring which demonstrated a distinct lack of appreciation for the scholarship that had gone before (see, for example, Beckford 2012; Calhoun et al. 2011; Kong 2010; Ley 2010). Abandoning secularisation as the overarching explanatory framework was too big a sacrifice for many (see, for example, Sweeney 2008). However, as reflections on postmodernity began to be taken seriously in social science, a challenge was presented, taking up the baton passed on by Bauman (1992), to wrestle with the issue of how to take difference seriously, and in so doing to rediscover the potential enchantment inherent in explorations of otherness. Such exploration included a reevaluation of the assumed boundaries of key categories of social scientific endeavour, including secular/religious divisions.

Social science responses to this question, of obvious relevance to geographers, have involved incorporating the increasing visibility of religion into existing social theory, identifying the return of religion as a reaction to the times; hence Castells' (1998) conception of the return of (fundamentalist) religion as a political force - but hardly a progressive one - and Davis' (2007) account of the importance of fundamentalist Pentecostal religion to slum dwellers as a response to their political and social marginalisation. However, the idea that religion may offer other kinds of potentials to society became more established in social science via engagement with Habermas. We detail the key ideas inherent in this engagement in Chapter 2, but one breakthrough notion was Habermas' recognition that religion represented a reservoir of cultural autonomy, with its pool of imaginary distinctiveness, that included moral and spiritual resources that could be a significant factor in the renewal of the social contract. In so doing, he 


\section{Introduction}

broached the possibility that the secular and the religious could be regarded as more equal partners in a more open-ended process of knowledge production, and thus created a peg on which to hang the further possibility that different understandings of religion may have a role to play in the process of re-enchantment.

As the secularisation thesis became more open to discussion, so other leading cultural and social theorists began to reference a postsecular condition (see, for example, Derrida 1998; Taylor 2007; Vattimo 2003 and Žižek 2001) and others (for example, Agamben 2005; Badiou 2003; Eagleton 2010) more specifically turned to religious discourse for new imaginaries about political intervention and radicalism. As Ward $(2009,131)$ comments, 'it is at this point, the point where religion has a public voice, that religion becomes political again', and it is important to note that this public voice became enabled via the production of new social science knowledge as well as being heard from religious and faithbased organisations themselves. As Ward further argues, the cultural reassertion in religious and other spiritualities of powerful mythic and mystical modes of thought, invoking a re-enchantment in senses of mystery and wonder, contributed both to a greater acknowledgement of the possibility of the sacred, and to a platform of dissatisfaction with, and critique of, neoliberalised secularity:

This cultural reassertion is the greatest single source of the desecularisation and resacralisation of the West. It is related to ... a more general re-enchantment of the real, a return to the mythic and the supernatural, a hastening dematerialisation, the increasing virtuality of the real, and the deepening mystification by many people about the complex scientific workings of quite ordinary things ...

(Ward 2009, 147)

Again, we need to emphasise a potential dark side to this assertion about deepening mystification; harmful religious delusions can sometimes be used to stabilise a threatened worldview without substantiation and in ways that produce deleterious effects of othering (see McIntosh and Carmichael 2016).

Interest in postsecularity, then, has emerged out of the nexus of contemporaneously recognising the possibilities for re-enchantment in the spiritual nature of religion and questioning the purported sufficiency of secularity. Despite the difficulties raised for some scholars by any use of the prefix 'post' (and the most difficult cheques/checks always seem to be 'in the post'), postsecularity, as McLennan (2007) observes, is neither built upon an intrinsic anti-secularism nor purports to suggest what comes after or instead of secularism. Rather, it serves as a heuristic conceptual device to question and probe the underlying assumptions of secularity, and in so doing to re-interrogate the faith-reason binary by recognising new modes of belief, new conditions for enactment of belief, and new ways in which the secular and the sacred may be becoming blurred. In short, postsecularity enables a critical engagement with the ways in which the boundless mystery and bounded structure of faith and reason can collaborate in the co-production of more hopeful spaces and subjectivities. 
Throughout the book, we examine these engagements and co-productions in considerable detail, but at this stage we want to signpost three particular currents that in our view have become very significant in putting flesh onto the bones of postsecularity: the receptive generosity (Coles 1997) necessary for social movements to perform ethics and politics appropriate to the underlying direction of postsecularity; the partnerships of rapprochement (Cloke and Beaumont 2013) that embody the values and potentials of postsecularity; and the pre-formative ethics of postsecularity that connect with the possibility of reconfigured desire and 'post-disenchantment' (Rose 2017).

\subsection{Three currents of postsecularity}

\section{The ethics and politics of postsecular caritas}

The first of these currents draws on the writings of political theorist Romand Coles (1997 and 2001; Hauerwas and Coles 2010) who explores the possibilities and practices of motivating a more radical sense of generosity within the social movements of radical democracy. Coles argues that ethical relations should be characterised and animated by a deliberately receptive form of generosity involving both an openness to the being and voices of others, as well as a desire to give them something of value:

The question involves a partly agonistic, partly co-operative - always transfiguring - dialogical effort with others to discern what is lower and what is higher; to discern how these differences and distances might be brought together and held apart such that we might become more receptive of their gifts, more capable of giving, less resentful and revenge-seeking, more radiant. This entwinement of giving and receiving is the precarious elaborating foundation of well-being and sense.

(Coles 1997, 22)

Unless generosity is fashioned in the context of a radical receptivity, he argues, its outcomes will fall short of that which was intended and will be prone to the kinds of violence, imperialism, and assimilation that he suggests have pervaded aspects of both religious and liberal activity in the public sphere. It is notable here that in claiming that overly strict boundaries have tended in the past to limit the numbers and characteristics of people who are able to take part in social movements, Coles is willing to embrace the radicalism located within the discourses of Christian religion, and is open to the possibility - theoretically, and in the agonistic and dialogic character of particular individuals and groups of human beings - that radical politics and radical ecclesia can collaborate in the textures of caring for others. In this way, he is content to mobilise the Christian values of 'caritas' (giving) and 'agape' (sacrificial love), but seeks to transfigure them, and notably the ideal of caritas, arguing for a wider sense of generosity in which no theological or secular position can claim absolute privilege for itself. 
He therefore delineates a postsecular caritas that seeks transformation through attentive listening, relationship-building, and careful tending to places, common goods, and diverse possibilities for flourishing.

Two particular values emerge from this vision of postsecular caritas. First, it seeks to shift political and theological imaginations beyond contemporary political formations, charting paths beyond the current political economy of endless growth and concentrated power that Coles sees as 'waging war on people and on our planet' (p. 218). This in turn poses pressing questions about exactly how social movements can mobilise their nature and possibility towards a communicative rationalisation of particular aspects of life, and in particular how they focus on the co-production of in-commonness that permit the concerns and engagements of receptive generosity to achieve greater depth and breadth of influence. In other words, how can ethical principles of postsecular caritas be marshalled in a morality of thinking as well as of doing, and how can self-other relations transcend enlightened self-interest and discover an ethics that cultivates both giving beyond equivalence and the truncation of revenge as signified by grace? Such principles require the cultivation of strong ethical sources, both ideological and theological. Second, how can postsecular caritas work across religious and secular boundaries, given that both territories will be required to forgo a privileging of their own position in order to sign up to the pursuit of transformative practices of attentiveness to in-commonness rather than tribal self-interest? The possibilities of postsecularity seem to rest on this capacity for this kind of mutual and receptive generosity in the practices that align social movements consisting of mixed foundational and motivational claims.

Some pointers to these values and questions emerge from a published exchange - Conversations between a Radical Democrat and a Christian between Coles (self-identifying as a member of no church) and Stanley Hauerwas a prominent public intellectual, theologian, and ethicist (Hauerwas and Coles 2010 - see also Hauerwas 1983 and 2000), in which the potential practicalities of a radical politics and ethics that 'goes beyond' secular and religious tribal allegiances are discussed in some detail. In the conversation, Coles is preoccupied by the question of how radical democracy can be exemplified by urban organising practices that engage a wide spectrum of people and bridge over political divisions. It is these local politics that in his view provide an ethical learning ground for receptive generosity that might then potentially infuse political work at other scales. Drawing on the work of the late John Howard Yoder, a Mennonite theologian who championed non-violent social activism (see, for example, Yoder 1994) - but also note his subsequent demise - (see Cramer et al. 2014), Coles acknowledges that religious dialogical communities can sometimes model powerful practices of generous solidarity, both in the creative use of conflict, and by being vulnerably receptive to marginalised people in and beyond the church. In this acceptance of some Christian ethical values and practices, Coles translates and develops an 'alien' religious discourse into his own idiom; but his transformation of religious ideas into his own secular frame is accompanied by a clear recognition that the characteristics that he finds admirable in Yoder's 
patient commitment to non-violence are inseparable from Yoder's Christocentric understanding of Christian discipleship. Postsecular caritas in this instance represents: generously recognising commendable ideas and practices from within alien belief-sets and being willing to use them across religious-secular boundaries; acknowledging the interconnections between ideas, practices, and beliefs, even if these beliefs are not shared; and being impressed that religious groups can be sufficiently confident in the dialogical process of confrontation and reconciliation to realise that they have got things wrong in the past and can learn from secular critique. In turn, Coles recognises the growth of (albeit wary and sometimes distrustful) alliances between secular movements and theological ideas:

What we see in a number of insurgent struggles is a radical-democratic tradition that is (becoming) distinct from Christian tradition and yet cultivating many proximate virtues and communities of character. Perhaps Bob Moses suggests this more haunting possibility, as may Myles Horton, Howard Zinn, Audrey Lorde, Judith Butler, Larry Goodwyn, Adrienne Rich, Tom Hayden, Saul Alinsky (somewhat), Charles Payne and a plethora of emergent radical-democratic communities reverberating across time. The haunting possibility is that there are traditions of radical-democratic practice that are arising, which, though indebted to several theological practices and visions, are developing admirable and possibly enduring capacities for seeing and moving across the world.

(Hauerwas and Coles 2007, 36)

This 'haunting possibility' of postsecular caritas at work in political movements rests on the possibility of a syncretic radical-democratic community that exceeds what was previously embodied by Christian and non-Christian ethics prior to the collaboration. The generative fusion of Christian and democratic traditions coproduces in Coles' mind more admirable imaginaries and practices than those inherited from more separate religious and secular positionings.

This generous expression of possibility, however, does not come without its worries. Clearly the process of being open to the being and voices of others is often accompanied by the kind of tensions, questions, doubts, and lack of trust that stem from asymmetries of power. As Coles asks: 'Might not ethical practice hinge very significantly on slackening the will to retain identity? Should Christians and radical-democrats have confidence that we have the far larger story and that our task is to outnarrate all the others?' (Hauerwas and Coles 2007, 42). Clearly this concern over an incapacity to tell big narratives without claiming particular identification for one side or other of the religious/secular divide is an issue that applies to all parties in a collaboration. However, the tendency for some religious movements to want to 'badge' social activities in ways that make them exclusive (see Cloke and Pears 2016a; 2016b) tends to legitimate the fear that faith-organisations may now be more adept than others at excluding alternative traditions and narratives from which they have a lot to learn. Coles' discussion of postsecular caritas, then, charts significant landscapes of possibility for 


\section{Introduction}

the co-production of postsecularity, but at the same time clearly identifies the need that syncretic social movements require a radical notion of insufficiency to underpin the collective receptive generosity that underpins such co-production.

\section{Postsecularity, rapprochement, and reterritorialisation}

Alongside Coles' recognition of the possibility of postsecular caritas in emergent social movements, geographers have also emphasised how the context of neoliberal austerity, with its shrinkage of the welfare state, has established a fertile landscape for the propagation of partnerships of religious and secular individuals and organisations seeking to step into the gap in order to meet the needs of marginalised and excluded people. Jack Caputo (2001) illustrates the empirical significance of religiously-motivated social action in the contemporary city:

If, on any given day, you go into the worst neighbourhoods of the inner cities of most large urban centers, the people you will find there serving the poor and needy, expending their lives and considerable talents attending to the least among us, will almost certainly be religious people - evangelicals and Pentecostalists, social workers with deeply held religious convictions, Christian, Jewish and Islamic, men and women, priests and nuns, black and white. They are the better angels of our nature. They are down in the trenches, out on the streets, serving the widow, the orphan and the stranger...

Certainly, within a Christianised Western framework, research has shown how faith-based organisations (FBOs) have become important in their own right as significant providers of non-statutory services of care and welfare, but also how these organisations have opened up new possibilities for wider involvement in ethical practices of postsecularity (see Beaumont and Cloke 2012). The specific contribution of FBOs has been clearly charted. The enduring significance of religious faith in the work of community mobilisation in deprived urban communities has meant that social, religious, and spiritual capital has been made available in particular localities via the spaces, time, organisational potential, and ethical motivation of faith-involvement (Baker and Skinner 2006). Moreover, FBOs have been shown to be frequent partners in progressive multiorganisational coalitions working for justice and against poverty. It is in the co-production of such partnership, in rapprochement (Cloke and Beaumont 2013), that ideas about spaces and subjectivities have found particular expression. Clearly some FBOs function primarily to support their own faith-networks, but others have been able to transcend these faith-boundaries in a range of different ways. Some consciously pursue a policy of professionalisation, sometimes subjugating their faith ethos to the wider objective of being recognised by secular clients and funders as well-trained, efficient, and open-to-all serviceproviders in a particular sector. In such cases (such as the Grooms-Shaftesbury organisation relaunched as 'Livability' and the Nationwide Festival of Light 
rebranded as 'Care') faith-ethos can be kept in the background, so as to enable secular as well as faith-motivated support. In other contexts, FBOs enter into deliberate partnership with secular and religious others to form more avowedly postsecular liaisons (such in the case of London Citizens - see Jamoul and Wills 2008). For such liaisons to be successful, partners need to agree on particular crossover narratives (see Chapter 2) in order to do something about the plight of socially excluded people in the city, and this may mean leaving divergent issues at the door in order to achieve the desired rapprochement.

Some geographical discussion of these phenomena has sought to temper their apparent significance (see, for example, Kong 2010; Lancione 2014; Wilford 2010). Seen in the context of longstanding attentiveness to both sacred and nonsacred spaces of religion, postsecular rapprochement can be interpreted as just the latest phase of a long-running attention to religion in the public sphere. Seen from the perspective of preserving geography as a critical secular space, ideas about rapprochement and postsecularity can be read as an attempt to introduce a normative defence of religion and religious values, and/or as an apologetic for joining in with neoliberal subject-formation. However, an alternative perspective is to be more sensitive (theoretically, epistemologically, empirically) to the expressions, organisations, and practices of postsecularity that may otherwise be masked by the ideological assumptions and driving forces of a universal and linear secularisation thesis. In other words, geographies of postsecular rapprochement may represent a radical departure in the understanding of contemporary society and space in which we refuse to be blind to partnerships involving religious praxis that we might otherwise ignore, or just assume do not exist. As Cloke and Beaumont $(2013,32)$ have argued:

It is our contention that there is potential within postsecular rapprochement to embody both an expression of resistance to prevailing injustices under neoliberal global capitalism, and an energy and hope in something that brings more justice for all citizens of our cities rather than simply rewarding the privileged few.

The argument here is for an understanding of the underlying conditions for potential reterritorialisation that may result from engagements with postsecularity. A more detailed examination of these underlying conditions is presented in Chapter 2, but it is worth noting at this stage the growing body of evidence suggesting that actual and potential activities of postsecularity are actively contributing to the reterritorialisation of cities, and smaller centres.

We examine these settings in detail in Chapters 3, 4, and 5, but, in summary, Cloke and Beaumont (2013) describe five types of response-spaces associated with postsecularity. First, there are places of affective response where the experience of obvious instances of socio-economic need induce a capacity to act within parts of the collective political and ethical conscience - places that cry out for 'something to be done about something', where a stark phenomenology of need prompts responses that deploy a willingness for rapprochement regardless of 


\section{Introduction}

potentially divisive differences. Issues such as homelessness, anti-trafficking, refugee support, and food insecurity have worked in just this manner to create an affective capacity that prompts new intersections and crossovers between faithmotivated and other actors. Second, there are spaces of resistance and subversion, evidenced, for example, in research on services for homeless and unemployed people (Cloke et al. 2010; Williams 2015; Williams et al. 2012). Here, rapprochement across perceived religious/secular divides can occur both inside government funding schemes and beyond, but is organised in such a way as to undermine or deflect the neoliberal politics involved, for example, by providing an excess of care beyond stipulated limits, or by using charitable resources in contravention of government ideologies (for example, serving homeless people on the streets when government is seeking to sweep such people off the streets). Third, there are spaces of voluntaristic and charitable cross-subsidy in which services located in more marginal areas of the city are delivered using resources from other places. Although spaces of postsecularity will often involve voluntary work by ex-clients, they depend mainly on labour and finance drawn from the participation and support of people from other areas of the city - often from the more affluent suburbs where the socially excluded victims of austere neoliberal regimes rarely present themselves in person. Of course, this kind of reterritorialisation can easily be critiqued in terms of guilttripping and 'moral selving' (Allahyari 2000) of the affluent middle classes; a minor charitable gesture that both absolves personal responsibility for the exclusionary nature of society and at the same time reinforces the divides that proliferate that exclusion. We would caution against such easy dismissal of charitable voluntarism, not only because it underestimates the sacrificial and affective nature of some voluntaristic involvement, but also because it fails to notice the capacity for gradual but attractional in-commonness (Popke 2009) that can develop therein. Jack Caputo (2001) points to the 'anarchic effects produced by re-sacralising the settled secular order' which are capable of producing an 'anarchic chaosmos of odd brilliant disturbances', which he sees as 'gifts that spring up like magic in the midst of scrambled economies' (p. 291). Rather than automatically characterising charitable cross-subsidy in the city entirely as a lightweight sop to the middle class conscience, we might pause to reflect on the possibility that in amongst this apparent charity there is scope for in-common encounters in which alterity is attended to in ways that can make deep impacts on conscience, ethicality and political conviction, and in registers where caritas and agape find anarchic expression that can disturb the scrambled economies of marginalisation and exclusion through performances of receptive generosity. In these kinds of ways, the flow of economic, social, and sometimes spiritual capital into the spaces of care in marginalised areas of cities develop sociospatial connections which unsettle not only perceived religious/secular boundaries but also geographical ones.

A fourth aspect of the reterritorialisation resulting from engagements with postsecularity involves the development of spaces of ethical identity. Here, we would point to the specific campaigning that aims to sponsor new ethical tropes 
such as City of Sanctuary and Fair Trade City (Amin 2006; Squire 2011; Darling 2010; Malpass et al. 2007). There is significant evidence to suggest that these campaign spaces reflect a range of religious and other interests, brought together to express values (for example, relating to hospitality, generosity, and responsibility) at the heart of which lie significant points of ethical convergence between theological, ideological, and humanitarian concern. In this case the conventional neoliberalised practices of marketing and branding places are being challenged or even usurped by a repositioning of cultural-political identity, drawing on rapprochements grounded in postsecularity. Similar spaces of ethical identity can also be recognised in more localised and ephemeral practices and events, and so a fifth strand of reterritorialisation is found in the myriad spaces of reconciliation and tolerance involving individuals and groups who are working across, or at least problematising, previous divides involving inter-religious, anti-religious, or anti-secular sentiment. Examples of such crossing of divides include antisectarian spaces (such as Co-exist in Glasgow) and peace-making spaces (such as the Bridges for Communities events in Bristol and Cardiff), although we also need to acknowledge here the possible negative outcomes that can occur when radical hospitality becomes too radical (see May 2018). At its root, this strand points to the embodied performances of identity - faith-motivated or otherwise in which local lived spaces can come to represent the potential for new forms of tolerance and agreement in place of previous sectarian tendencies. Although more attention is usually given to the spaces of postsecularity that are organised by specific groups of activists in well-signalled initiatives, this smaller-scale and less prominent performative embodiment of postsecularity and rapprochement is equally if not more significant in its likely impact on the ordinary and everyday geographies of different spaces.

These five types of spaces of postsecularity are neither mutually exclusive nor exhaustive, but they provide initial evidence of the possibility of emergent hopeful geographies of in-common seeking after the common good. The ethics and politics of Romand Coles' postsecular caritas seem to be finding expression both in some recognisable social movements, and in some more modest sites of ethical activity. While it would be wrong to suggest any one driving force behind these initiatives, the increased activities of FBOs are a significant component in the development of different forms of rapprochement, and are certainly making their mark in city-spaces and beyond, both in putting into praxis theological and theographical (Sutherland 2017) ethics and politics, and in opening out meetingplaces for wider partnerships with other individuals and organisations. These interventions are now part of what the contemporary city is. Given that the city represents a scale of religious identity and practice that best permits the organisation of faith-motivated action, both within and beyond faith boundaries, there is clear need to examine and assess the significance of this re-emergence and reformulation of the sacred within the wider development and spaces of urban communities; how new forms of re-engagement of faith and politics, or faith and ethics, are sponsoring particular virtues of in-commonness and common good within areas of governance, service delivery, and social protest. Moreover, 


\section{Introduction}

despite scalar disadvantages, it is important not to ignore how such rapprochement is also taking place in more rural environments (see Jones and Heley 2016), where action, for example, on homelessness (Cloke et al. 2007), and food poverty (Williams et al. forthcoming) is beginning to gain pace. As well as reflecting how things are, the lens of postsecularity also offers insights into how the contemporary city (and its more rural counterparts) could be. Baker and Beaumont (2011b) suggest that spaces of postsecularity in the city serve as liminal spaces in which citizens are able to journey from the unshakeable certainties of particular worldviews with their extant comfort zones, to the unknown real and imagined spaces of rapprochement. So, for example, volunteers in spaces of care such as food banks will often find their initial political and/or religious assumptions questioned as they enter into relations of in-commonness both with hungry clients and with other volunteers with different assumptions (see Williams et al. 2016). In this way, partnerships of postsecularity could represent laboratories in which elements of self-interest and control are ceded to the greater aim of 'doing something about' social injustice and caring for others, and in the process, there are possibilities for transformations in ethical discourse and praxis. These ethical laboratories could be built on ideas of receptive generosity and rapprochement, which offer scope for reterritorialising socially divided spaces. However, there is a crucial third strand that underpins the idea and practice postsecularity - the potential for re-enchantment.

\section{Assemblages of hopeful re-enchantment}

In their account of the relationship between religion and contemporary activism in the Occupy movement, Cloke et al. (2016) argue that religious involvement helped to facilitate progressive crossover narratives that enabled both to discern the spiritual aspects of capitalism, and to galvanise prepolitical values of hope, faith, and love in the context of prefigurative projects of economic democracy and social liberation. In recognising capitalism as a regime of desire, emergent politics and ethics of postsecularity engage with the possibility of working towards a reformulation of prepolitical desire around notions of receptive generosity, respect for alterity, and reaching out with agape and caritas to neighbours and to enemies; that is, postsecularity works towards the reshaping of subjectivities by combatting neoliberal structuring of desire with new resonances of reenchantment.

Weber's (1976) argument connecting capitalist modernism with processes of disenchantment is very familiar; in a disenchanted world, he argues, public life has been stripped of ultimate and sublime values as scientific rationalism and bureaucracy have replaced the magical, the mysterious, and the incalculable. Commentaries on the impacts of contemporary secularised neoliberalism have pointed to just such disenchantment in the current age. According to Blond (1998) - an author who identifies both as Christian and as 'Red Tory' - secular frameworks for advancing science and economics have been reproduced into the arenas of politics and ethics, risking a dangerous complicity with an ontology of 
violence that champions self-centred individualism and standardises the priority of force and counter-force. The result is a kind of hopeless vacuity in which the weakening of mysticism becomes characterised by endless self-serving acts of negation and denial, and self-seeking desire fed by the machinic power of commodity fetishism. Cloke and Beaumont (2013) regard this hopelessness as 'a weary acceptance in some quarters that how we live is circumscribed by the market-state's ability to shape how we govern ourselves', implying for many a 'broad disavowal of any possibility that social melancholia and desperation might be transformed or transfigured' (p. 39 - see also Milbank 2006). In a collective sense, the form and content of neoliberalism have placed boundaries on what pleasure can be and undermined more hegemonic regimes of desire. In such a context, Critchley (2012) and Ward (2009) describe the paralysis of empty nihilism in which the only discernible telos lies in the individual pursuit of pleasure. This individualisation of desire, and the associated erosion of notions of the community and the broader social, have resulted particularly in intensified class divisions often tightly constrained within social bubbles of sameness; living alongside people with similar circumstances and modes of dwelling, and not only reducing encounters with less privileged others but also actively feeding the neurosis of autonomous desire that often leads to stigmatising stereotypes of others-as-enemies (see Reinhard 2005). Re-enchantment, then, involves attention to both self-to-self and self-to-other pleasure and desire.

Weber further argues that the disenchanting work of capitalism is reinforced by its ties to particular forms of religion, and these ties have been increasingly and destructively imbricated in the era of neoliberal austerity. Connolly (2005 and 2008) describes how this Evangelical-Capitalist Resonance Machine in the United States represents an alliance between dogmatic 'cowboy capitalism' and right-wing evangelical Christianity that shores up and inspires the politics of existential resentment and hubris that have been largely responsible for much of the economic inequality, socio-cultural enmity, environmental degradation, and short-sighted parochialism of contemporary life. The capitalist axiomatic of prioritising private profit, granting unquestioned credence to market forces, and commodifying unjust labour formats is justified and stretched out by a form of judgemental and vengeful right-wing religion that too often espouses individual prosperity and extreme moral conservatism. The one resonates with and amplifies the other in a darkly reactionary form of fusion. In one sense, this crossover between conservative Christianity and conservative politics might be regarded as 'postsecular' in nature, but its complicity with a lack of interconnection between self-to-self and self-to-other desire contrasts strongly with our notion of "postsecularity', that is, a condition of being that prioritises receptive generosity over exclusive ownership of theo-ethics.

The idea that society has travelled from an enchanted past through a disenchanted present to a possibly re-enchanted future is, of course, an oversimplistic model of social and cultural change that easily underestimates the ambivalences and overlaps that best of each of these supposed categories. However, the possibility of re-enchantment, including the return of magic, mystery, and irrationality, 


\section{Introduction}

has been much discussed. As Lyons (2014) indicates, many such attempts to reimagine enchantment have in effect sought to revise the secularisation thesis, not by challenging the idea that modernity has inflicted fatal wounds on religion, but by contesting Weber's identification of modernity with a lack of enchantment. A stream of recent writing (see for example, Bennett 2011; Landy and Saler 2009; Levine 2008; Saler 2011) has suggested that modernity does not straightforwardly disenchant the world; rather it produces an entirely new array of secular strategies that yield often superior - if paradoxical - versions of enchantment. According to Levine (2008) and Bennett (2011) respectively, these secular enchantments inspire an excited affirmation of things in the world, and motivate ethical and political engagement in opposition to, or stretching beyond the capitalist machine. To some extent secular re-instatement of enchantment leans on the capacity of the postmodern to restore to the world what modernity had denuded it of; a reinvigoration of initiative and authorship of action, and the right to give meaning to and construe narratives counteracted a de-spiritualised and de-animated model of the world in which the capacity of the subject had gone missing.

A significant direction in the development of these geographies of secular reenchantment has been the willingness to address the issue of a restored ontology of agency in both the human and non-human world. This return to an enchanted secular Cosmopolitics - or, in Blok and Farias' $(2016,5)$ terms, an 'ontological' or 'object-centred' politics - has its roots in the work of the Bruno Latour and Isabelle Stengers in the early years of this century, which is further developed by McFarlane (2011) and his ideas of urban assemblage. A fully-fledged ontological politics not only taps into the desire for a non-materialistic and more ethically grounded form of civic and political participation that we are suggesting lies at the centre of postsecularity. It also highlights the progressive and innovative potential of new assemblages of Cosmopolitics that often centre on everyday struggles of survival and dignity, especially for those on the margins.

Baker (2018a) has identified four significant aspects of these ontological politics. First, as suggested by Blok and Farias (2016), the human and non-human objects that co-construct our urban assemblages are not 'objects' in the standard sense of the word; rather they are relationally intended, and in shaping our 'shared, common public matters' they therefore come 'loaded with moral and political capacities' (p. 7). This radical co-presence helps to shape how urban realities are made and remade, and in turn generates a series of innate and virtual possibilities leading to a new surplus of knowledge and affect that transcend existing binaries and old signifiers. This excess or surplus of meaning and affect is the second significant aspect of the ontological politics of secular re-enchantment, and in turn leads to a third, given that the excess or surplus of meaning and affect impels us to want to make their inherent potential more visible. Blok and Farias are clear that this visualisation of the inherent and the potentially possible is not only a research imperative $(2016,5)$, but also a politico-ethical one that in turn generates new politico-ethical subjectivities, based on a common understanding of the singularity of moral intent and ontological depth that lies beneath the urban. Fourth, these 
emerging political-ethical subjectivities, involving as they do the decisive decentring of the human subject and previous knowledge about how material reality is 'produced', in turn create new forms of political imagination and praxis. 'It is important to stress,' say Blok and Farias $(2016,7)$, that 'this ontological multiplicity does not just point to the different furniture of human worlds, but to different ways of "being human", of assembling and enacting humanity.' This manifesto for a new political imagination it seems to us, could, and does, potentially 'cross over' (Cloke 2015) into religious, spiritual and non-religious sites of practical urban engagement; 'a politics of exploring and provisionally settling what does and does not belong to our common [urbanised] worlds' (Farias and Blok 2016, 7). Chapters $3,4,5$, and 7 explore and analyse in greater detail the many dimensions of this new ontological politics of postsecularity, containing as they do these four elements of radical co-presence, an excess of new knowledge and affect, the emergence of new politico-ethical subjectivities, and new forms of political imagination and praxis.

However, alongside this secular turn to an ontologically-heavy politics based on the 'real' and 'moral' power of each object within any given urban assemblage, a significant segment of the envisioning of re-enchantment has embraced the values and critical capacities of left-leaning religion, arguing that a crisis of secular consciousness requires new spaces and subjectivities of spiritual disobedience in which hierarchies, dispositions, and deeply held beliefs can be reworked. In their evaluation of Occupy, Cloke et al. (2016) exemplify this kind of spiritual disobedience:

We suggest that Occupy needs to be understood at least in part as a deeply spiritual and sacramental protest, not solely in its aims and objectives, but in its practices, its hospitality to otherness, and in its offer of direct experience of mutualism and radical democratic forms of organising. The solidarity practices within encampments offered a deeply spiritual counter-formation to the affective repercussions of capitalist liturgies (or discourses) that saturate our everyday lives. Counter-neoliberal liturgies that enforce an alternative spiritual and ethical worldview to the neoliberal entreaty to consume, behave and be comfortable can be a pragmatically meditative resource for producing a hopeful subjectivity, that operates beyond a symbolic understanding or attachment to the capitalist order, recognising its perversity, and more able to imagine and embody prefigurative possibilities for living.

These ideas about new prefigurative politics and ethics involving progressive elements of religion are firmly embedded in Connolly's (1999) answer to the Evangelical-Capitalist Resonance Machine. He articulates the need to imagine, narrate, develop, and experiment with a new movement of the democratic left that will be organised across religious, class, gender, ethnic, and generational lines, and will be infused with an ethos of radical pluralism. He contends that the 
distinction between secular public and religious private life needs to be reworked, and that traditional ideas about unity and solidarity need to be translated into drives to form new kinds of provisional assemblages comprised of multiple constituencies and creeds. In identifying this 'politics of becoming', Connolly, a self-identified non-theist, notes the importance of the Christian left to an alternative kind of resonance machine; he advocates 'movements back and forth between registers of subjectivity' (including religious and other registers) in order that 'each infiltrates into the others' (p. 148), recognising the potential for re-enchantment arising from this process. He draws both on a meliorism that prioritises collective reflective action, and on Deleuzian notions of immanence in a world that is always becoming. Taken together, moments of reflexive and coincidental postsecularity can emerge as key components of re-enchantment. Religious and secular dispositions can be made to resonate in ways that reenchant a world stripped of its mystery, ineffability, and virtually impossible.

Connolly's new politics of becoming resonates with the other strands of postsecularity discussed above. Receptive generosity is a prerequisite for reflexive inter-subjectivity. A willingness and capacity for rapprochement prefigures any tactical pursuit of reflexive and coincidental hopefulness. At its core, however, the seeking after of assemblages of hopeful re-enchantment involves a remodelling of the subjectivities of desire away from those inflicted by capitalist hegemony, and towards those that are fed by a counter-cultural, and sometimes theological, ethic that confronts and secedes from neoliberal regimes of desire (prioritising wealth, self-interest, and self-pleasure) in order to cultivate an affective capacity for hopefulness and healing, hospitality and generosity, justice and equality. This process involves not only a reshaping of desire, but also experimentation with new affective rhythms and with new capacities to be affected by those rhythms. Such a remodelling will be connected with the cultivation of a pre-political ethicality relevant not only to material life, but also to an affective psycho-spiritual life; ethicality that reflects a protean movement of hopeful postsecularity that begins to take shape in and around impossibility as well as possibility, and indeterminacy as well as determinacy, as found in the geographies and temporalities being moved through and that contextualise becoming (Holloway 2011a). In one sense, following Rose (2017), re-enchantment may not be the best term to describe this new hopefulness of postsecularity, given that the 'entangling networks which constitute contemporary capitalism function as a system of technological re-enchantment' and constitute a 'secular reiteration of the kinds of structures of power and domination which characterised the enchanted universe of classical Christian thought' ( $p$ 243). As we discuss in Chapter 3, postsecularity perhaps sits more easily under Rose's banner of 'postdisenchantment', recognising a break from both classical Christian enchantment and from subsequent re-enchantments that reinforce the resonances between neoliberalism and the religious right. As our book progresses, we will examine evidence of contemporary post-disenchantment evident in lines of flight associated with the subjectivities (Chapter 3) and spaces (Chapter 4) of postsecularity. 


\subsection{Geographies of postsecularity}

In what follows we examine these three interconnected modalities of postsecularity - receptive generosity, partnership, and re-enchantment - following a number of different trajectories. Chapter 2 presents a detailed exploration of the philosophical underpinnings of the concept. It traces key moments of debate concerning the role of religion in the public life of liberal democracies, beginning with the insistence (for example, by John Rawls and Robert Aldi) that religious narratives and ideas should be subjugated to and translated into secular equivalents so that the privilege of public secularity could be maintained. It then proceeds to the seminal, but much debated contribution of Jurgen Habermas; for some little different to the anti-religious defence of the secular that went before, but for others the protagonist for a more even-handed approach to religious and secular roles in public thought, and the 'godfather' of postsecularity. We discuss in detail his key ideas, especially his explanation of how crossover narratives emerge from the engagement of mutual tolerance across religious/secular boundaries, and of how mutual translation across these boundaries permits reasoning that can be accepted by religious citizens and secular citizens alike. Mutual translation, then, leads to complementary learning, which in turn facilitates a potential assimilation of ideas and a reflexive transformation of thinking which can lead to the acceptance of religious ideas into public policy. Rather than envisaging any wholesale acceptance of religious legitimation for public action, we understand postsecularity as a capacity to hold together the combined discourses and praxis of secular and religious citizens, enabling broad-based alliances to be built on a willingness to focus on ethical sympathies and practices, even if that means setting aside potential moral differences. For such alliances to achieve anything approaching rapprochement, secular and faith-based fundamentalisms need to be set aside, allowing primordial ethical and political currents to emerge in the pre-political realm that can subsequently flourish without being crushed or co-opted by neoliberal capitalism. We argue that the spaces and subjectivities of postsecularity may be most evident in the traces, flows, fragrances, and affective tolerances that are formed out of a mutual sense of theopoetics, and become part of Connolly's politics of becoming in which new energies and lines of flight emerge from the power of powerlessness, the possibility of impossibility and the translation of theo-ethics of peace, generosity, forgiveness, mercy, and hospitality into everyday praxis of care and justice for the other.

In Chapter 3 we examine the subjectivities of postsecularity as part of the wider conceptual recalibration of the notion of the postsecular. We begin by drawing on poststructural and non-representational approaches to subjectivity, affect and ethics to provide a definitional discussion of what is meant by subjectivities of postsecularity. We take postsecularity as a thirdspace where the blurred boundaries between religious and secular belief, practice, and identity can undergo reflexive engagement and produce new ethical and political subjectivities. By nature, religious and secular subjectivity has always been mutually coconstituted; yet, we contend that the intensity of new forms of enchantment, the 


\section{Introduction}

deterritorialisation of propositional modes of religious and secular belief and practice, alongside postures towards receptive generosity, represents something that demands academic attention. We identify a series of tectonic shifts that have led to the erosion of religious and secular fundamentalisms and the bubbling up of subjectivities of postsecularity. We wish to draw attention to the constitution of secular and religious subjectivities under late-capitalist and neoliberal regimes of desire and suggest ways in which existential ressentiment and spiritual ennui might facilitate, as well as serve as a bulwark to, a willingness to enter into the space of postsecularity. The chapter then traces four possibilities presented by postsecularity in this existential and political-economic context: (i) as an opportunity in neoliberal austerity to retain practices of solidarity and amplify an ethics of in-commonness associated with new movements beyond religious and secular fundamentalism; (ii) as a mode of active resistance to neoliberal subjectification which has become marked by an ignorance and vindictiveness towards the 'other'; (iii) as an affective politics of hope that cuts through prevailing affective atmospheres of neoliberalism to solicit a 'hope of the hopeless' grounded in the non-foundational theopoetics of the impossible; and (iv) as a mode of post-disenchantment, where we explore the new ethics, values, and practices emanating from dissatisfaction with allures of religious and latecapitalist enchantment. We then explore how new ethical capacities and subjectivities of postsecularity emerge in practice. Here we draw on examples of the Pauluskerk, a faith-based harm reduction project in Rotterdam, The Netherlands; practices of solidarity and rapprochement in the Jungle camps in Calais, France; the work of the Third Sector in post-disaster Christchurch, New Zealand. We conclude the chapter by discussing how might our theorisation of postsecularity benefit from recent geographic work on the event.

Chapter 4 examines the variegated geographies of postsecularity, drawing on a series of empirical examples to illustrate how distinct spatial contexts afford different opportunities and barriers for subjectivities of postsecularity to emerge. The chapter begins by mapping a range of social and political spaces which have been incubators for subjectivities of postsecularity. This list is not intended to be mutually exclusive or exhaustive. Rather our purpose is to examine how postsecularity is differently produced, mobilised towards different ends, and generative of specific formulations of political and ethical subjectivity. To illustrate this, we compare two spheres of activity - neoliberalised spaces of welfare, and environmental activism - as a way of foregrounding the different discourses, practices, and spaces that curate different possibilities for partnership between religious and secular voices. We then offer a critical examination of how the three modalities of receptive generosity, rapprochement, and the reconfiguration of desire are manifest 'on the ground'. This is developed through two case-studies drawn from the arena of welfare and care in the UK: drug and alcohol treatment and recovery, and emergency food aid provision. In each arena emergent postsecularity is shown to be generative of, and shaped by, different configurations of the religious and the secular, opening out distinct political and ethical possibilities. Within this, 
however, we draw attention to the power entanglements and contradictions often embedded in rapprochement.

Chapter 5 examines postsecularity in terms of its progressive political utility. We begin by recognising that the centrality of ethical negotiation in postsecular politics is what distinguishes it from other political modalities. We argue that this ethical negotiation emerges from a common political and affective conjuncture that binds people across different ethico-political predilections and generates new modes of affective and political being which have been examined in recent research on activist practices such as community organising and hospitality. We use the example of participatory art practice as a way to illustrate that the postsecular transformations can occur in mundane and creative spaces as well as more obviously politically charged ones. We argue that spaces of care, quotidian rhythms, and creativity can be facilitated by politically minded activists, translating ethical proximity and affective commonality into politically charged action. This looks different in different postsecular modalities. Regarding re-enchantment, we give the example of religious activists grounding the speculative ontology of radical theorists such as Žižek (2000) and Badiou (2003) in order to question the legitimacy of hegemonic constructions of the Other. In the case of receptive generosity, we examine the use of 'techniques of self' (Connolly 1999; Foucault 2005) in religious communities whose communal structure empowers and practically supports heterogeneous forms of activism. Finally, apropos of rapprochement, we analyse the creation and development of crossover narratives in the Occupy movement, which served a pragmatic role in focussing action and subsequently evolved so as to generate novel subjectivities, partnerships, and political tactics. To conclude the chapter, we suggest - first that postsecular analysis and tactics can help to forge new 'progressive coalitions' (Klein 2017) in politics by seizing back the psycho-spiritual terrain of politics from neoliberalism. Second, we suggest that by seizing back the terrain of psychology and spirituality from neoliberalism, new ontological approaches to politics can be embraced by progressive political movements that blend liberated desire, sense of place, and ethical sensitivity. Finally, we argue that these developments can generate new possibilities for participatory action research that blends ethics, politics, and spirituality.

In Chapter 6 we interrogate a central critique that associates postsecularity with a perceived Western and Euro-centrism, and the argument that it loses cultural and critical traction once it leaves that privileged locus. We echo calls for empirical sensitivity towards the spatial formations of postsecularity beyond the Christian-secular nexus of engagement. Equally, we warn against making normative assumptions about how postsecularity works out in practice and emphasise the danger of theorisation that is ungrounded in sociohistorical contingency. However, we argue that the global and hegemonic attempts in the nineteenth and twentieth centuries to impose a series of discrete models of Western secularism on colonial and now post-colonial cultures have left their imprint on the twentyfirst century, creating a series of affective, spatial, and policy practices across non-Western social-spatial and historical contingencies. These provide a more 


\section{Introduction}

nuanced analysis of our interpretation of postsecularity as receptive generosity, rapprochement/partnership, and re-enchantment.

The chapter identifies key aspects in the changing geographies of secularism, secularity, religion, and belief which produce highly localised and uneven capacities for postsecularity to emerge in different places. To highlight these contingencies, we trace our three-fold definition of postsecularity through existing literatures and key debates. First, we discuss gender identity and agency with regard to postsecular feminism and the identities of Muslim women in Turkey, and elsewhere. Here we note the entangled religious and secular identities and public performativities and highlight the possibilities for political conscientisation and new forms of rapprochement between secular and religious Muslim women. Second, we consider the potential rapprochement linked to changing perceptions in international development and humanitarian studies of the traditional relationship between the religious and the secular. Third, we suggest global variants of secularism are becoming increasingly fragmented and blurred through changing geographies of modernity, religion, and belief, and highlight the changing state-religion relationships in China, Russia, and India to raise questions about the localised and highly variegated possibility for postsecularity to emerge in situ. Last, we draw on perspectives of assemblage and actor network theory to expand our understanding of the ways that 'the religious' reproduces urban modernities, and vice versa. Through these illustrations we seek to offer a critical perspective that is attentive to the diverse and ambivalent terrain upon which the three modalities of receptive generosity, rapprochement, and hopeful enchantment might be curated.

We conclude by suggesting that the differentiated and lived out fields of the religious and the secular identified by Bourdieu, Casanova, and Taylor, so characteristic of previous understandings of modernity, are becoming increasingly blurred and hybridised across global settings. We end by drawing on the work of post-colonial literary theorist Manav Ratti who foregrounds emerging postcolonial literatures which are marked by new forms of hopeful ethics that seek new conceptions of secularism and religion. We go on to develop this theme of postsecularity as spaces and politics of hope in the final chapter.

Chapter 7 concludes this volume by analysing how the arguments we have built up throughout our narrative demonstrate how postsecularity is, first, affecting politics presently, and second, creating possibilities for future political and academic action. We address contemporary politics by reviewing Chapters 1 to 6 , not to reiterate our arguments but to present the specific political salience of postsecularity in each chapter, focussing particularly on how its renegotiation of the secularism/religion interface fosters its political importance. Regarding future political and academic action, we present four arguments. First, we argue that the performativity of postsecularity can generate networked resonances which can impact the predominant political affects of late capitalism - fear, ressentiment, listlessness, and ennui - supplanting it with love, hope, and enchantment. Second, postsecularity opens up activism to an a/theistic spirituality that could reinvigorate the Left by reconnecting praxis with desire and 
steering new practices of generosity away from 'dark' postsecularity. Third, postsecularity can provide new maps for political analysis and action, generating a greater understanding of, and openness to, the fluidity of praxis. Finally, we provide a series of questions that postsecularity raises for human geography, creating new directions for research that interrogate the blending of religious and political concerns in critically appraised and ethically pluralised ways. 


\section{Subjectivities}

fire he put it on and has never taken it off at any public engagement since. 'Now', he says, 'my role is much more public, and I need to be identifiable' suggesting a new valuing and relaxation regarding public religious identity. It is unclear wherever we will eventually see the same level of acceptance of other public religious symbols, such as the hijab, emerge as part of the wider, national healing and cohesion that could come out of the awful trauma of this event. In his account of the healing and cohesion facilitated by faith groups in the aftermath, Baker (2017b) notes that the public performance by churches, mosques, and other secular institutions and individuals played a key role in denouncing the 'blind logic of managerialism' and its cost-cutting algorithms that rationalised the lack of sprinklers and the use of combustible cladding. The groundswell of ethical response, both nationally and within the local community, worked in part to restore webs of connectivity and hope, as the event instigated new imaginations of social value that extended across and through time and place. The aftermath of the Grenfell Tower disaster shows postsecularity across religious and secular differences arising spontaneously in the affective response of compassion, grief, and solidarity; as well as the suspension and reformulation of prevailing sacred/secular distinctions. What has been revealed by Grenfell has come to manifest a 'truth process' (Badiou cited in Cloke et al. 2017, 72), producing community subjectivities marked by politicised hope and collective struggle against local authorities, and a national clarion call of disenchantment that refutes the ethical credibility of neoliberal technologies of outsourcing and 'efficiency savings'.

\section{Note}

1 We would like to acknowledge our debt to Justin Beaumont for initial conversations on the spiritual negation and ennui of neoliberalism. 


\section{Spaces}

sensitive re-reading of these spaces, attuned for difference not domination (Gibson-Graham 2006; May and Cloke 2014). In this way, religious and secular collaboration in spaces of welfare can be re-read as liminal and transitional spaces of encounter, deliberation, and transformation. In this conceptualisation emphasis shifts to an analysis of precorporation and the politics of ethics itself. As the foodbank case-study demonstrated, in these spaces there is nascent potentiality for the unlearning of ethico-political attitudes - stances of cynicism, individualism, materialism - and the curation of new ethical and political subjectivities. The claim is not one of exclusivity: we are not claiming that religion, or spaces of postsecularity more specifically, are somehow guaranteed to be successful in bringing about these transformations. Rather, there is a potential within these spaces, a vibrant openness that sparks off intuitive and dialogical negotiations of previously held beliefs and ways of being in the world. In a context where the search for authenticity, or the 'search for God after God' has become increasingly important among both the religious and non-religious (Baker 2017a), spaces of postsecularity might offer new avenues for sacralisation. The translatability between 'God' and 'love', as discussed by Caputo (2001), as practiced in care for the marginalised might generate complex processes of re-sacralisation of compassionate in-commonness. Neoliberal governance mediates the expression of compassion through restrictive eligibility, deservingness, conditionality, sanctions, austere rationing and downgrading of support, breathing life into myths of individualisation, culpability and responsibility. This is not a celebratory call for charitable sentimentality but a political recognition of the potential, at least, in spaces of postsecularity for sacralisation of the 'other', whereby values of receptive generosity become foundational to understandings of responsibility. In doing so, we might better understand that the existential cultures of unbelief (Lee 2015) are not marked by disenchantment but entail a contested array of new forms of sacralisation where embodied dispositions towards justice take on qualities of what is considered sacred. Last, the process of creating new myths that inspire solidarity, hope, and love are key aspects of performative postsecularity (Stacey 2017), and in doing so acknowledges the paucity of the myths we have lived by, become subject to, and have divided sensibilities of in-commonness into individualised silos of religion, identity, and belief.

\section{Notes}

1 This reading of curation comes from recent theological literature on inclusivity, creativity, and worship, particularly the work of Pierson (2012) and Baker J (2010). This theme of curation has also been recently developed in relation to new processes of partnership between faith groups, local authorities, and the public sector around themes of hope and spiritual capital in the work of Barber (2017).

2 We thank Wiley-Blackwell and Sage for granting us permission to re-use some material from two published papers: Williams A (2015) Postsecular geographies: theoethics, rapprochement and neoliberal governance in a faith-based drug programme. Transactions of the Institute of British Geographers, 40, 192-208. Williams A, Cloke 
P, May J and Goodwin M (2016) Contested space: the contradictory political dynamics of food banking in the UK. Environment and Planning A, 48(11), 2291-2316.

3 Discussion is drawn from a two-month ethnographic placement working in a Salvation Army run 'Lifehouse' and drug programme. Daily involvement in the centre entailed working alongside staff and residents on the detox and rehabilitation wing of the building. Alongside participant observation, documentary analysis and extensive conversations recorded in a fieldwork journal, taped interviews were conducted with 14 of the centre's staff and volunteers and six residents at different stages of the treatment programme. 
possible, political subjects need to move past the political status quo of secular parliamentarianism and embrace a new way that speaks to liberated desire. We argue that postsecularity is a way for subjects to explore new ontological approaches to politics which - following Connolly's (1999) reading of Nietzsche (1974) - recognises the fragile texture of ethical predilections and moves towards a subjectivity that is willing to tarry a little longer with difference (see Anzaldúa 2012). Although this is taking postsecularism to its extremity, we argue that it can lead to a new type of political consciousness like the Zapatistas' (Mentinis 2014) or Anzaldúa's Mestiza. ${ }^{8}$ It is a consciousness that is willing to dislocate from the current symbolic order in order to channel something more enchanting and intangible, allowing the subject to imagine alternative futures that include ideological outliers and grey areas. Although the Zapatistas and Anzaldúa are firmly rooted in the left-wing political lexicon, how might recognition of the mystical elements of their ontologies be identified in other groups and ideologies and interrogated for their political implications and seen as political partners? Using a postsecular lens, we can more effectively blend geographies of politics and religion as our illustrations of Moody (2012) and Ganiel's (2006) work on speculative ontologies demonstrate. It is at these interstices of politics, religion, and spirituality that some of the dimensions of enchanted secular ontology that generate surpluses of meaning and affect in assemblages of the public (as reflected upon in Chapter 1) comes into play.

Third, we recognise that the arguments presented in this chapter generate new possibilities for participatory action research in human geography. Postsecularity creates a new way of assessing the political terrain that is built on finding crossovers and generating both openings to novel subjectivities and broad bricolaged resonances across difference. What new types of political tactics and actions can be dreamt up? And what are the new ontologies and end goals we can base these on? In this chapter we have examined a grounding of speculative ontologies through arts practice, faith communities that support their inherent political diversity, and new forms of hospitality built on increasingly broad networks of mutual aid. What new kinds of activism can be generated by conversations that blend politics and spirituality and that focus on bridging between deeply felt desire or pain and ethics? Postsecularity inspires us to dream up new ways of being together, and to address the question: how can geographers extend their participant activist research to begin to blend spirituality, politics, and ethics more consciously?

\section{Notes}

1 This identification of the parallels between Taylor (1987), and Deleuze and Guattari (1994) is drawn from Holloway's (2011) chapter on spiritual geographies.

2 Eagleton (2011) suggests this opening to 'raw possibility' is a kind of ressentiment that problematically suggests that progress can be made without ethical negotiation. This is an ego-move that tries to cover over the subject's weakness and fear; their inability to find the energy to engage in the difficult work of ethics or their worry that however much ethical work is put in, nothing will change for the better. Eagleton (2011) argues 


\section{Political practices}

that refusing to admit our limitations in the sometimes-terrifying futility of ethical work and reliance on the emergence of an ethically justifiable event is a kind of evil.

3 This is as opposed to conceptualising postchristendom as the phenomenon or social reality which Murray (2011) defines as 'the culture that emerges as the Christian faith loses coherence within a society that has been definitively shaped by the Christian story and as the institutions that have developed to express Christian convictions decline in influence' (p. 19).

4 For an in-depth discussion of these processes, see Sutherland 2017.

5 For discussion of how these types of knowledge affect the construction of theology see Beckford 1998; Gutiérrez 1988; Holland 2015; Rohr 2003; Talvacchia 2014; Williams 2013.

6 For explanation of 'Homelessness Sunday', see Housing Justice 2018.

7 Using Christian symbolism and staging as part of crossover narratives in pluralistic movements is not unique to Occupy. See Sutherland's (2016) work on working class protests in the UK's Midlands against the 'crucifixion' of local libraries.

8 See also the political role of Rastafarianism and Peace Concerts in Marlon James' (2014) novel A Brief History of Seven Killings. 
past done in the name of either one or the other, but also nurture 'the hope for a better future for all'.

We have nuanced Ratti's rather abstract call for a new post-colonial postsecular imagination with five lived dimensions of postsecularity derived from our exploration of non-Western, and where possible, non-Judeo-Christian debates concerning the postsecular. First is the strong sense of religion being perceived as a threat to established secular orders in nation states in terms of national security and radicalisation. However, the more the State attempts to control religion and belief, the more it simply re-enters the public sphere in adapted ways, such as cultural heritage or tourism, welfare engagement or political art. Second, is the appeal to alternative ethical subjectivities and understandings of agency that the postsecular turn demands. This is particularly true of the ways in which non-Western feminist notions of power, agency, and autonomy, along with ideas of intersectionality are being reformulated. Third, is the emphasis on religious/ secular hybridities, which are by and large absent from Western discourse and which highlights the postcolonial dimension of the discourse. Fourth is the growing sense that the idea of the nation state also needs to be reimagined if a new way of dealing with diversity is to be achieved. For example, we have seen how eliciting notions of lived accommodation within localised performances of tolerance, hospitality, and the sharing of space are being increasingly scaled up to offer policy clues at the macro level. Fifth, it encourages a focus on the interpenetration of the religious and the secular at the level of material production of urban and social space, thus reinforcing our belief that postsecularity is a way of being that expresses itself in new material structures, ethical practices, and forms of governance. We now take some of these themes into our final chapter, where we critically define the emerging contours of postsecularity as the basis for a sustained and credible politics of hope.

\section{Note}

1 This conference was organised by the Institute for Religion, Culture and Public Life, University of Columbia, 10/11 November 2011. 


\section{Bibliography}

Ackerman B (1994) The Future of Liberal Revolution. Newhaven, CT, Yale University Press.

Adamson J (2017) The City That Fell To Its Knees. Independently published, Christchurch. Agamben G (1998) [1995] Homo Sacer: Sovereign Power and Bare Life. Stanford, CA: Stanford University Press.

Agamben G (2005) The Time That Remains. Stanford, CA: Stanford University Press.

Ager A and Ager J (2011) Faith and the Discourse of Secular Humanitarianism. Journal of Refugee Studies, 24(3), 456-472.

Ahmad M and Rae J (2015) Women, Islam and Peacemaking in the Arab Spring. Peace Review, 3, 312-319.

Al Qurtuby S (2013) Peacebuilding in Indonesia: Christian-Muslim Alliances in Ambon Island. Islam and Christian-Muslim Relations, 24(3), 349-367.

Aldridge A (2000) Religion in the Contemporary World: A Sociological Introduction. Cambridge: Polity Press, 2nd Edn.

Alinsky SD (1971) Rules for Radicals: A Practical Primer for Realistic Radicals. New York, NY: Random House.

Allahyari R (2000) Visions of Charity: Volunteer Workers and Moral Community. Berkeley, CA: University of California Press.

Amin A (2006) The Good City. Urban Studies, 43, 1009-1023.

Anderson B (2012) Affect and Biopower: Towards a Politics of Life. Transactions of the Institute of British Geographers, 37(1), 28-43.

Anderson B (2014) Encountering Affect: Capacities, Apparatuses, Conditions. Abingdon, Oxon: Ashgate.

Anderson B (2016) Neoliberal Affects. Progress in Human Geography, 40(6), 734-753.

Anderson B and Harrison P (2010) Taking-Place: Non-Representational Theories and Geography. Farnham: Ashgate.

Anzaldúa G (2012) Borderlands/La Frontera: The New Mestiza. San Francisco, CA: Aunt Lute Books.

Arab American Tribe (2015) The Economic Approach: Cooperatives and Coexistence as a means to Peace in Israel and Palestine. Available from https://arabAmericantribe. wordpress.com/2015/09/24/the-economic-approach-cooperatives-and-coexistence-asa-means-to-peace-in-israel-and-palestine/ (last accessed 27/07/18).

Asad T (2003) Formations of the Secular: Christianity, Islam, Modernity. Stanford: Stanford University Press.

Ash J and Simpson P (2016) Geography and Post-Phenomenology. Progress in Human Geography, 40(1), 48-66. 
Askins K (2015) Being Together: Everyday Geographies and the Quiet Politics of Belonging. ACME: An International Journal for Critical Geographies, 14(2), 470-478.

Askins K and Pain R (2011) Contact Zones: Participation, Materiality, and the Messiness of Interaction. Environment and Planning D, 29, 803-821.

Atia M (2012) 'A Way to Paradise': Pious Neoliberalism, Islam, and Faith-Based Development. Annals of the Association of American Geographers, 102, 808-827.

Atlani L, Caraël M, Brunet J-B, Frasca T, and Chaika N (2000) Social Change and HIV in the Former USSR: The Making of a New Epidemic. Social Science and Medicine, $50,1547-1556$.

Audi R (1989) The Separation of Church and State and the Obligations of Citizenship. Philosophy and Public Affairs, 18, 259-296.

Audi R (1997) Liberal Democracy and the Place of Religion in Politics. In Audi R and Wolterstorff N (eds) Religion in the Public Square. London: Rowman \& Littlefield Publishers, pp. 1-66.

Auerbach NN (2012) Delicious Peace Coffee: Marketing Community in Uganda. Review of Radical Political Economics, 44(3), 337-357.

Augé M (1988) A Sense for the Other: The Timelessness and Relevance of Anthropology. Stanford, CA: Stanford University Press.

Badiou A (2003) [1997] Saint Paul: The Foundation of Universalism. Tran. Ray Brassier. Stanford, CA: Stanford University Press.

Baker C (2009) Hybrid Church in the City: Third Space Thinking. London: SCM/Canterbury Press, 2nd Edn.

Baker C (2012) Spiritual Capital and Economies of Grace: Redefining the Relationship between Religion and the Welfare State. Social Policy and Society, 11(4), 565-576.

Baker C (2013) Current Themes and Challenges in Urban Theology. The Expository Times, 125, 3-12.

Baker C (2016) Faith in the Public Sphere - In Search of a Fair and Compassionate Society for the Twenty-First Century. Journal of Beliefs and Values, 37, 259-272.

Baker C (2017a) Ministry and Authenticity. Anvil: Journal for Theology and Mission, 33(3), 30-37.

Baker C (2017b) Creating Webs of Connectivity and Hope. Church Times. 28 July 2017. Available from www.churchtimes.co.uk/articles/2017/28-july/comment/opinion/ creating-webs-of-connectivity-and-hope (last accessed 20/07/18).

Baker C (2018a) Resisting the Transcendent. In Beaumont J (ed.) The Routledge Handbook of Postsecularity. London and New York: Routledge.

Baker C (2018b) Postsecularity and a New Urban Politics - Spaces, Places and Imaginaries. In Berking H, Steets S and Schwenk J (eds) Religious Pluralism and the City: Inquiries into Postsecular Urbanism. London: Bloomsbury, pp. 81-101.

Baker C and Beaumont J (2011a) Postcolonialism and Religion: New Spaces of 'Belonging and Becoming' in the Postsecular City. In Beaumont J and Baker C (eds) Postsecular Cities: Space, Theory and Practice. London: Continuum, pp. 33-49.

Baker C and Beaumont J (2011b) Afterword: Postsecular Cities. In Beaumont J and Baker C (eds) Postsecular Cities. Continuum: London, pp. 254-266.

Baker C and Skinner H (2006) Faith in Action: The Dynamic Connection Between Spiritual and Religious Capital. Manchester: William Temple Foundation.

Baker J (ed.) (2010) Curating Worship. London: SPCK Publishing.

Barbato M (2012) Postsecular Revolution: Religion After the End of History. Review of International Studies, 38(5), 1079-1097. 
Barbato M and Kratochwil F (2008) Habermas's Notion of a Post-Secular Society. A Perspective from International Relations. EUI Working Papers. MWP 2008/25. Florence, Italy: European University Institute.

Barber M (2017) Curating Spaces of Hope: A New Definition and Model of Faith-Based Organisations. William Temple Foundation, Temple Tracts 5(3) Available from https://williamtemplefoundation.org.uk/wp-content/uploads/2017/12/Matthew-BarberSpaces-of-Hope.pdf (last accessed 02/08/18).

Barbieri W (ed.) (2014) At the Limits of the Secular: Reflections on Faith and Public Life. Grand Rapids, MI: Wm. B. Eerdmans Publishing.

Barnes M and Prior D (eds) (2009) Subversive Citizens: Power, Agency and Resistance in Public Services. Bristol: Policy Press.

Barnett C (2017) The Priority of Injustice: Locating Democracy in Critical Theory. Athens, GA: University of Georgia Press.

Barnett C, Cloke P, Clarke N, and Malpass A (2005) Consuming Ethics: Articulating the Subjects and Spaces of Ethical Consumption. Antipode, 37, $23-45$.

Barrett A (2017) Interrupting the Church's Flow: Engaging Graham Ward and Romand Coles in a Radically Receptive Political Theology in the Urban Margins. Amsterdam: VU University of Amsterdam.

Barthes R (1972) [1957] Mythologies trans. Annette Lavers. New York: Hill and Wang.

Bartley J (2006) Faith and Politics After Christendom: The Church as a Movement for Anarchy. Milton Keynes: Paternoster Press.

Bartolini N, Chris R, MacKian S, and Pile S (2017) The Place of Spirit: Modernity and the Geographies of Spirituality. Progress in Human Geography, 41(3), 338-354.

Bartolini N, MacKian S, and Pile S (eds) (2018) Spaces of Spirituality: An Introduction. In Bartolini N, MacKian S and Pile S (eds) Spaces of Spirituality. London and New York: Routledge, pp. 1-24.

Battaglia G (2017) Neo-Hindu Fundamentalism Challenging the Secular and Pluralistic Indian State. Religions, 8(10), 216-236.

Bauman Z (1992) Intimations of Postmodernity. London: Routledge.

Beaumont J (2008a) Introduction: Faith-Based Organisations and Urban Social Issues. Urban Studies, 45, 2011-2017.

Beaumont J (2008b) Faith Action on Urban Social Issues. Urban Studies, 45, 2019-2034.

Beaumont J and Baker C (eds) (2011) Postsecular Cities: Space, Theory and Practice. London: Continuum Press.

Beaumont J and Cloke P (eds) (2012) Faith-Based Organisations and Exclusion in European Cities. Bristol: Policy Press.

Beaumont J and Dias C (2008) Faith-Based Organisations and Urban Social Justice in the Netherlands. Tijdschrift voor Economishe en Sociale Geografie, 99, 382-392.

Becker J, Klingan K, Lanz S, and Wildner K (eds) (2013) Global Prayers: Contemporary Manifestations of the Religious in the City. Baden: Lars Muller Publishers.

Beckford J (2012) SSSR Presidential Address Public Religions and the Postsecular: Critical Reflections. Journal for the Scientific Study of Religion, 51, 1-19.

Beckford R (1998) Jesus is Dread: Black Theology and Black Culture in Britain. London: Darton, Longman and Todd.

Bell DM (2001) Liberation Theology after the End of History: The Refusal to Cease Suffering. New York: Routledge.

Bender C and Taves A (eds) (2012) What Matters? Ethnographies of Value in a not so Secular Age. New York: Columbia University Press. 
Bennett B, Dann J, Johnson E, and Reynolds R (eds) (2014) Once In A Lifetime: Citybuilding After Disaster in Christchurch. Christchurch, Freerange Press.

Bennett J (2011) The Enchantment of Modern Life. Princeton, NJ: Princeton University Press.

Berger P (1967) The Sacred Canopy. New York: Doubleday.

Berger P (1969) A Rumor of Angels: Modern Society and the Rediscovery of the Supernatural. New York: Doubleday.

Berger P (ed.) (1999) The Desecularization of the World: Resurgent Religion and World Politics. Grand Rapids, MI: Eerdmans.

Berger P, Davie G, and Fokas E (2008) Religious America, Secular Europe? Aldershot: Ashgate.

Berlant L (2011) Cruel Optimism. Durham, NC: Duke University Press.

Berridge V (2005) Temperance: Its History and Impact on Current and Future Alcohol Policy. Joseph Rowntree Foundation, York.

Berry D (2017) Religious Strategies of White Nationalism at Charlottesville. Religion \& culture forum. Available from https://voices.uchicago.edu/religionculture/ 2017/10/13/religious-strategies-of-white-nationalism-at-charlottesville/ (last accessed 20/07/18).

Bialecki J (2017) Eschatology, Ethics, and Ēthnos: Ressentiment and Christian Nationalism in the Anthropology of Christianity. Religion and Society, Sept 42-61.

Bielo J (2011) Emerging Evangelicals - Faith, Modernity and the Desire for Authenticity. New York: New York University Press.

Bielo J (2013) Belief, Deconversion, and Authenticity Among US Emerging Evangelical. Ethos, 40(3), 258-276.

Blaser M (2014) Ontology and Indigeneity: On the Political Ontology of Heterogeneous Assemblages. Cultural Geographies, 21(1), 49-58.

Blest P (2017) Over 80,000 People Joined the Biggest-Ever Moral March in North Carolina. The Nation. 13 February 2017. www.thenation.com/article/over-80000-peoplejoined-the-biggest-ever-moral-march-in-north-carolina/ (last accessed 20/07/18).

Blok A and Farias I (eds) (2016) Urban Cosmopolitics: Agencements, Assemblies, Atmospheres. New York: Routledge.

Blond P (1995) Theology and Pluralism. Modern Theology, 11, 455-469.

Blond P (1998) Introduction: theology before philosophy. In Blond P (ed.) Post-secular Philosophy: Between Philosophy and Theology. London: Routledge, pp. 1-66.

Blond P (2010) Red Tory. London: Faber and Faber.

Bloomquist KL (2012) Ekklesia in the Midst of Outrage. Dialog: A Journal of Theology, 51(1), 62-70.

Blühdorn I (2006) Self-Experience in the Theme Park of Radical Action?: Social Movements and Political Articulation in the Late-Modern Condition. European Journal of Social Theory, 9(1), 23-42.

Boeskov K (2017) The Community Music Practice as Cultural Performance: Foundations for Community Music Theory of Social Transformation. International Journal of Community Music, 10(1), 85-99.

Bondi L (2013) Between Christianity and Secularity: Counselling and Psychotherapy Provision in Scotland. Social \& Cultural Geography, 14(6), 668-688.

Bosch D (2011) Transforming Mission. Maryknoll, NY: Orbis Books. Twentieth Anniversary edition.

Bourgois P (2000) Disciplining Addictions: The Bio-politics of Methadone and Heroin in the United States. Culture Medicine and Psychiatry, 24, 165-195. 
Bourgois P and Hart L (2010) Science, Religion and the Challenges of Substance Abuse Treatment. Substance Use \& Misuse, 45(14), 2395-2400.

Braidotti R (2008) In Spite of the Times: The Postsecular Turn in Feminism. Theory, Culture \& Society, 25(6), 1-24.

Braun LN (1997) In from the Cold: Art Therapy with Homeless Men. Art Therapy Journal of the American Art Therapy Association, 14(2), 118-122.

Bretherton L (2010a) Christianity and Contemporary Politics: The Conditions and Possibilities of Faithful Witness. Oxford: Wiley-Blackwell.

Bretherton L (2010b) Religion and the Salvation of Urban Politics: Beyond Cooption, Competition and Commodification. In Molendijk A, Beaumont J, and Jedan C (eds) Exploring the Postsecular: The Religious, the Political and the Urban. Leiden: Brill, pp. 207-222.

Bretherton L (2011) The Real Battle of St. Paul's Cathedral: The Occupy Movement and Millennial Politics. Huffington Post. www.huffingtonpost.co.uk/luke-bretherton/thereal-battle-of-st-pau_b_1065214.html (last accessed 28/08/2015).

Brewin K (2010) Other: Embracing Difference in a Fractured World. London: Hodder \& Stoughton Ltd.

Brinkman R and Brinkman J (2008) Globalisation and the Nation-State; Dead or Alive. Journal of Economic Issues, 42, 425-433.

Brogt E, Grimshaw M, and Baird N (2015) Clergy Views on their Role in City Resilience: Lessons from the Canterbury Earthquakes. Kotuitui: New Zealand Journal of Social Sciences Online, 10(2). Available from www.tandfonline.com/doi/full/10.1080/ 1177083X.1068186 (last accessed 29/03/18).

Bruce S (ed.) (1992) Religion and Modernisation: Sociologists and Historians Debate the Secularization Thesis. Oxford: Oxford University Press.

Brueggemann W (1978) The Prophetic Imagination. Minneapolis, MN: Fortress Press.

Bryant L, Srnicek N and, Harman G (2011) The Speculative Turn: Continental Materialism and Realism. Melbourne: re.press.

Bugyis E (2015) Postsecularism as Colonialism by Other Means. Critical Research on Religion, 3(1), 25-40.

Burbridge C (2013) Faith and the Politics of 'Other': Community Organising Amongst London's Congolese Diaspora. London: Contextual Theology Centre.

Butler J (1990) Gender Trouble. New York: Routledge.

Button M (2005) 'A Monkish Kind of Virtue'? For and Against Humility. Political Theory, 33(6), 840-868.

Calhoun C, Juergensmeyer M and VanAntwerpen J (eds) (2011) Rethinking Secularism. Oxford: Oxford University Press.

Campbell L and Zimmerman Y (2014) Christian Ethics and Human Trafficking Activism: Progressive Christianity and Social Critique. Journal of the Society of Christian Ethics, 34(1), 145-172.

Caputo J (2001) On Religion. London: Routledge.

Caputo J (2006) The Weakness of God: A Theology of the Event. Bloomington, IN: Indiana University Press.

Carey G (2011) The Occupy Protest at St. Paul's Cathedral - A Parable of our Times. Daily Telegraph 27 October.

Carroll A and Norman R (eds) (2016) Religion and Atheism: Beyond the Divide. London: Routledge.

Carvalho S (2017) A Week In The Jungle - Volunteering At The Refugee Camp In Calais. The Huffington Post. Available from www.huffingtonpost.co.uk/santoshcarvalho/calais-jungle_b_12312682.html (last accessed 21/07/18). 


\section{Bibliography}

Caryl C (2013) Strange Rebels: 1979 and the Birth of the 21st Century. New York: Basic Books.

Casanova J (1994) Public Religions in the Modern World. Chicago, IL: University of Chicago Press.

Casanova J (2011) Public Religions in the Modern World. Chicago, IL: University of Chicago Press, 2nd Edn.

Castells M (2011) The Power of Identity. Oxford: Wiley-Blackwell, 2nd Edn.

Cavanaugh W (1998) Torture and Eucharist: Theology, Politics, and the Body of Christ. Oxford: Blackwell.

Cavanaugh W (2014) Invention of Religious-Secular Distinction. In Barbieri WA (ed.) At the Limits of the Secular: Reflections on Faith and Public Life. Grand Rapids, MI: Wm. B. Eerdmans, pp. 105-128.

Çavdar A (2013) Negotiations as a Research Methodology. In Becker J, Klingan K, Lanz $\mathrm{S}$ and Wildner K (eds) Global Prayers: Contemporary Manifestations of the Religious in the City. Baden: Lars Müller Publishers, pp. 198-215.

Caygill H (2002) Levinas and the Political. London: Routledge.

Chan SH (2017) Religious Competition and Creative Innovation Amongst Protestant Groups in Hong Kong's Umbrella Movement. Asian Journal of Religion and Society, 5(1), 23-48.

Chau A (ed.) (2011) Religion in Contemporary China: Revitalization and Innovation. London and New York: Routledge.

Chesters G and Welsh I (2006) Complexity and Social Movements: Multitudes at the Edge of Chaos. London: Routledge.

Christianity Uncut Website: http://christianityuncut.wordpress.com (last accessed 27/08/2018).

Christoyannopoulos A (2011) Christian Anarchism: A Political Commentary on the Gospel. Imprint Academic: Exeter.

Chu C (ed.) (2014) Catholicism in China, 1900-Present. New York: Palgrave Macmillan.

Cistelecan A (2014) The Theological Turn of Contemporary Critical Theory. Telos, $167,8-26$.

Citizens UK Website: www.citizensuk.org/ (last accessed 15/05/2018).

Claiborne S (2006) The Irresistible Revolution: Living as an Ordinary Radical. Grand Rapids, MI: Zondervan.

Clarke N, Barnett C, Cloke P, and Malpass A (2007) Globalising the Consumer: Doing Politics in an Ethical Register. Political Geography, 26, 231-249.

Cloke P (2002) Deliver us from Evil? Prospects for Living Ethically and Acting Politically in Human Geography. Progress in Human Geography, 26(5), 587-604.

Cloke P (2010) Theo-ethics and Radical Faith-Based Praxis in the Postsecular City. In Molendijk A, Beaumont J, and Jedan C (eds) Exploring the Postsecular: The Religious, the Political and the Urban. Brill, Leiden, pp. 223-241.

Cloke P (2011a) Emerging Postsecular Rapprochement in the Contemporary City. In Beaumont J and Baker C (eds) Postsecular Cities: Space, Theory and Practice. London: Continuum, pp. 237-253.

Cloke P (2011b) Emerging Geographies of Evil? Theo-ethics and Postsecular Possibilities. Cultural Geographies, 18, 475-493.

Cloke P (2016) Crossover: Working Across Religious and Secular Boundaries. In Cloke P and Pears M (eds) Mission in Marginal Places: The Theory. Milton Keynes: Paternoster Press, pp. 145-167. 
Cloke P and Beaumont J (2013) Geographies of Postsecular Rapprochement in the City. Progress in Human Geography, 37(1), 27-51.

Cloke P and Conradson D (2018) Transitional Organisations, Affective Atmospheres and New Forms of Being-in-common: Post-disaster Recovery in Christchurch, New Zealand. Transactions of the Institute of British Geographers (online first). doi. org/10.1111/tran.12240.

Cloke P and Dickinson S (2019) Transitional Ethics and Aesthetics: Re-imagining the Post-disaster City in Christchurch, New Zealand. Annals of the Association of American Geographers (in press).

Cloke P and Pears M (eds) (2016a) Mission in Marginal Places: The Theory. Milton Keynes: Paternoster Press.

Cloke P and Pears M (eds) (2016b) Mission in Marginal Places: The Praxis. Milton Keynes: Paternoster Press.

Cloke P and Sutherland C (Forthcoming) Conceptualising Social Protection: Evaluating Third Sector Practice between the Universal and the Local.

Cloke P and Williams A (2018) Geographical Landscapes of Religion. In Baker C, Crisp B, and Dinham A (eds) Re-imagining Religion and Belief for 21st Century Policy and Practice. Cambridge: Policy Press, pp. 33-54.

Cloke P, Beaumont J, and Williams A (eds) (2013) Working Faith: Faith-based Organisations and Urban Social Justice. Milton Keynes: Paternoster Press.

Cloke P, Dickinson S, and Tupper S (2017) The Christchurch Earthquakes 2010, 2011: Geographies of an Event. New Zealand Geographer, 73(2), 68-80.

Cloke P, Johnsen S, and May J (2005) Exploring Ethos? Discourses of 'Charity' in the Provision of Emergency Services for Homeless People. Environment and Planning A, 37, 385-402.

Cloke P, Johnsen S, and May J (2007) The Periphery of Care: Emergency Services for Homeless People in Rural Areas. Journal of Rural Studies, 23, 387-401.

Cloke P, May J, and Johnsen S (2007) Ethical Citizenship? Volunteers and the Ethics of Providing Services for Homeless People. Geoforum, 38, 1089-1101.

Cloke P, May J, and Johnsen S (2010) Swept Up Lives? Re-envisioning the Homeless City. Oxford: Wiley-Blackwell.

Cloke P, May J, and Williams A (2017) The geographies of food banks in the meantime. Progress in Human Geography, 41(6), 703-726.

Cloke P, Sutherland C, and Williams A (2016) Postsecularity, Political Resistance, and Protest in the Occupy Movement. Antipode, 48(3), 497-523.

Cloke P, Thomas S, and Williams A (2012) Radical Faith Praxis? Exploring the Changing Theological Landscape of Christian Faith Motivation. In Beaumont J and Cloke P (eds) Faith-based Organisations and Exclusion in European Cities. Bristol: Policy Press, pp. 105-126.

Cloke P, Thomas S, and Williams A (2013a) Faith in Action: Faith-based Organization, Welfare and Politics in the Contemporary City. In Cloke P, Beaumont J, and Williams A (eds) Working Faith: Faith-based Organisations and Urban Social Justice. Milton Keynes: Paternoster, pp. 1-24.

Cloke P, Williams A, and Thomas S (2013b) CAP in Two Guises: A Comparison of Christians Against Poverty and Church Action on Poverty. In Cloke P, Beaumont J, and Williams A (eds) Working Faith: Faith-based Organisations and Urban Social Justice. Milton Keynes: Paternoster, pp. 25-46.

Coles R (1997) Rethinking Generosity: Critical Theory and the Politics of Caritas. Ithaca, NY: Cornell University Press. 


\section{Bibliography}

Coles R (2001) Traditio: Feminists of Color and the Torn Virtues of Democratic Engagement. Political Theory, 29(4), 488-516.

Connolly W (1999) Why I am Not a Secularist. Minneapolis, MN: University of Minnesota Press.

Connolly W (2005) The Evangelical-Capitalist Resonance Machine. Political Theory, 33, 869-886.

Connolly W (2008) Capitalism and Christianity, American Style. Durham, NC: Duke University Press.

Conradson D (2003) Spaces of Care in the City: The Place of a Community Drop-in Centre. Social and Cultural Geography, 4, 507-525.

Conradson D (2013) Somewhere Between Religion and Spirituality? Places of Retreat in Contemporary Britain. In Hopkins P, Kong L, and Olson E (eds) Religion and Place: Landscape, Politics, and Piety. New York, NY: Springer, pp. 185-202.

Cooke M (2006) Re-presenting the Good Society. Cambridge, MA: MIT Press.

Cox J (2015) Taxpayers Subsidise Big Business by an Estimated £11 Billion a Year. Citizens UK. 12 April 2015. www.citizensuk.org/taxpayer (last accessed 20/07/18).

Cramer D, Howell J, Martens P, and Tran J (2014) Theology and Misconduct: The Case of John Howard Yoder. The Christian Century, 131(17), 20-24.

Critchley S (2012) The Faith of the Faithless: Experiments in Political Theology. London: Verso Books.

Crouch W (2011) The Strange Non-Death of Neo-Liberalism. Cambridge: Polity Press.

Cupples J and Glynn K (2009) Countercartographies: (New Zealand) Cultural Studies/ Geographies of the City. New Zealand Geographer, 68, 1-5.

Cvetkovich A (2012) Depression: A Public Feeling. Durham, NC: Duke University Press.

Dabashi H (2012) The Arab Spring. London: Zed.

Dalferth I (2010) Post-secular Society: Christianity and the Dialectics of the Secular. Journal of the American Academy of Religion, 78, 317-345.

Daniel W and Marsh C (2008) Russia's 1997 Law on Freedom of Conscience in Context and Retrospect. In Daniel W, Berger P, and Marsh C (eds) Perspectives on ChurchState Relations in Russia. Waco TX: Baylor University Press.

Darling J (2010) A City of Sanctuary: The Relational Re-imagining of Sheffield's Asylum Politics. Transactions of the Institute of British Geographers, 35, 125-140.

Davelaar M, Williams A, and Beaumont J (2013) Adventures at a Border-Crossing: The Society for Diaconal Social Work in Rotterdam, the Netherlands. In P Cloke, J Beaumont, and A Williams (eds), Working Faith: Faith-based Organizations and Urban Social Justice. Milton Keynes: Paternoster Press, pp. 165-184.

Davie G (2007) The Sociology of Religion. London: SAGE.

Davie G (2015) Religion in Britain: A Persistent Paradox. Oxford: Wiley-Blackwell.

Davies T, Isakjee A, and Dhesi S (2017) Violent Inaction: The Necropolitical Experience of Refugees in Europe. Antipode, 49(5), 1263-1284.

Davies W (2011) The Political-economy of Unhappiness. New Left Review, 71, 65-80.

Davis C, Milbank J, and Žižek S (2011) The Monstrosity of Christ: Paradox or Dialectic? Cambridge, MA: MIT Press.

Davis J (1997) Building from the Scraps: Art Therapy within a Homeless Community. Art Therapy - Journal of the American Art Therapy Association, 14(3), 210-213.

Davis M (1990) City of Quartz: Excavating the Future in Los Angeles. London: Verso.

Davis M (2007) Planet of Slums. London: Verso.

Dawkins R (2007) The God Delusion. London: Bantam. 
Day D (1997) The Long Loneliness. New York, NY: HarperCollins.

de Vries H (2006) Introduction: Before, Around and Beyond the Theologico-political. In de Vries H and Sullivan L (eds) Political Theologies: Public Religions in a Postsecular World. New York: Fordham University Press, pp. 1-88.

Deleuze G and Guattari F (1994) What is Philosophy? New York, NY: Columbia University Press.

della Dora V (2016) Infrasecular Geographies: Making, Unmaking and Remaking Sacred Space. Progress in Human Geography, 42(1), 44-71.

Della Porta D (2005) Multiple Belongings, Tolerant Identities, and the Construction of 'Another Politics': Between the European Social Forum and the Local Social Fora. In Della Porta D and Tarrow S (eds) Transnational Protest and Global Activism. Oxford: Rowman \& Littlefield Publishers, pp. 175-202.

Democracy Now! (2017) Cornel West \& Rev. Traci Blackmon: Clergy in Charlottesville Were Trapped by Torch-Wielding Nazis. Democracy Now! 14 August 2017. Available from www.democracynow.org/2017/8/14/cornel_west_rev_toni_blackmon_clergy (last accessed 20/07/18).

Deneulin S and Rakodi C (2011) Revisiting Religion: Development Studies Thirty Years On. World Development, 39(1), 45-54.

Depoortere F (2008) Christ in Postmodern Philosophy: Gianni Vattimo, Rene Girard, and Slavoj Žižek. London: T\&T Clark International.

Derrida J (1994) Specters of Marx: The State of the Debt, the Work of Mourning, and the New International, trans. Peggy Kamuf. London: Routledge.

Derrida J (2002) 'Faith' and 'Knowledge': The Two Sources of 'Religion' at the Limits of Reason Alone. In Derrida J and Vattimo G (eds) Religion. Cambridge: Polity Press, pp. 1-78.

Dewsbury JD (2000) Performativity and the Event: Enacting a Philosophy of Difference. Environment and Planning D, 18, 473-496.

Dewsbury JD (2003) Witnessing Space: 'Knowledge without Contemplation'. Environment and Planning A, 35(11), 1907-1932.

Dewsbury JD (2007) Unthinking Subjects: Alain Badiou and the Event of Thought in Thinking Politics. Transactions of the Institute of British Geographers, 32(4), 443-459.

Dewsbury JD and Cloke P (2009) Spiritual Landscapes: Existence, Performance and Immanence. Social \& Cultural Geography, 10, 695-711.

Dillon M (2010) Can Post-Secular Society Tolerate Religious Differences? Sociology of Religion, 71, 139-156.

Dinham A and Lowndes V (2008) Religion, Resources, and Representation: Three Narratives of Faith Engagement in British Urban Governance. Urban Affairs Review, 43(6), 817-845.

Dionne E Jnr (2008) Souled Out: Reclaiming Faith and Politics After the Religious Right. Princeton, NJ: Princeton University Press.

Diprose G (2015) Negotiating Contradiction: Work, Redundancy and Participatory Art. Area, 47(3), 246-253.

Dittmer J (2008) The Geographical Pivot of (the End of) History: Evangelical Geopolitical Imaginations and Audience Interpretation of Left Behind. Political Geography, 27(3), 280-300.

Dittmer J and Sturm T (2010) Mapping the End Times: American Evangelical Geopolitics and Apocalyptic Visions. Farnham: Ashgate Publishing.

Doak M (2007) The Politics of Radical Orthodoxy: A Catholic Critique. Theological Studies, 68(2), 368-393. 


\section{Bibliography}

Doel M (1994) Deconstruction on the Move: From Libidinal Economy to Liminal Materialism. Environment and Planning A, 26, 1041-1059.

Doel M (1995) Bodies without Organs: Schizoanalysis and Deconstruction. In Pile S and Thrift N (eds) Mapping the Subject: Geographies of Cultural Transformation. London: Routledge.

Dossett W (2013) Addiction, Spirituality and 12-Step Programmes. International Social Work, 56(3), 369-383.

Douch P (2005) The Busker's Guide to Inclusion. Eastleigh: Common Threads Publications Ltd.

Duff C (2017) The Affective Right to the City. Transactions of the Institute of British Geographers, 42(4), 516-529.

Dunnington K (2011) Addiction and Virtue. Downers Grove, IL: InterVarsity Press USA.

Dwyer C (2016) Why Does Religion Matter for Cultural Geographers? Social \& Cultural Geography, 17, 758-762.

Dwyer C and Parutis V (2013) 'Faith in the system?' State-funded Faith Schools in England and the Contested Parameters of Community Cohesion. Transactions of the Institute of British Geographers, 38, 267-284.

Eagleton T (2009) Trouble with Strangers: A Study of Ethics. Chichester: John Wiley \& Sons Ltd.

Eagleton T (2010) Reason, Faith and Revolution. London: Yale University Press.

Eagleton T (2011) On Evil. New Haven, CT: Yale University Press.

Eberle C (2002) Religious Conviction in Liberal Politics. Cambridge: Cambridge University Press.

Eder K (2002) Europaische sakularisierung- ein sonderweg in die postsakulare gesellschaft. Berliner Journal für Soziologie, 3, 331-343.

Eder K (2006) Post-Secularism: A Return to the Public Sphere. Eurozine. 17 August.

Ehrkamp P and Nagel C (2014) 'Under the Radar': Undocumented Migrants, Christian Faith Communities, and the Precarious Spaces of Welcome in the US South. Annals of the Association of American of Geographers, 104, 319-328.

Eisenstein C (2011) Sacred Economics: Money, Gift, and Society in the Age of Transition. New York, NY: Evolver Editions.

Ekklesia (2011) 'Sermon on the Steps' Response to the Bishop of London's Ultimatum. Available from www.ekklesia.co.uk/node/15616 (last accessed 28/08/2015).

End Hunger UK (2017) End Hunger UK: A Menu to End Hunger in the UK. Available from http://endhungeruk.org/wp-content/uploads/2017/12/A-Menu-to-End-Hunger-in-the-UK. pdf.

Epstein B (2002) The Politics of Prefigurative Community: The Non-Violent Direct Action Movement. In Duncombe S (ed.) Cultural Resistance Reader. London: Verso, pp. 333-346.

Everett A (2018) After the Fire: Finding Words for Grenfell. London: Canterbury Press Norwich.

Fairbanks R (2009) How it Works: Recovering Citizens in Post-welfare Philadelphia. Chicago: University of Chicago.

Faith in the City (1985) Faith in the City: The Report of the Archbishop of Canterbury's Commission on Urban Priority Areas. London: Church House Publishing.

Farias I and Bloc A (2016) Introducing Urban Cosmopolitics: Multiplicity and the Search for a Common World. In Bloc A and Farias I (eds) Urban Cosmopolitics: Agencements, Assemblies, Atmospheres. London: Routledge, pp. 1-22. 
Featherstone D, Ince A, Mackinnon D, Strauss K, and Cumbers A (2012) Progressive Localism and the Construction of Political Alternatives. Transactions of the Institute of British Geographers, 37(2), 177-182.

Ferguson H (1995) Melancholy and the Critique of Modernity Søren Kierkegaard's Religious Psychology. London: Routledge.

Ferguson J and Gupta A (2002) Spatialising States: Toward an Ethnography of Neoliberal Governmentality. American Ethnologist, 29(4), 981-1002.

Finley S (2000) 'Dream Child': The Role of Poetic Dialogue in Homeless Research. Qualitative Inquiry, 6(3), 432-434.

Finley S and Finley M (1999) Sp'ange: A Research Story. Qualitative Inquiry, 5(3), 313-337.

Firth R (2016) Somatic Pedagogies: Critiquing and Resisting the Affective Discourse of the Neoliberal State from an Embodied Anarchist Perspective. Ephemera, 16(4), 121-142.

Fisher A (2017) Big Hunger: The Unholy Alliance between Corporate America and AntiHunger Groups. Cambridge, MA: The Massachusetts Institute of Technology Press.

Fisher AS (2005) Developing an Ethics of Practice Applied Theatre: Badiou and Fidelity to the Truth of the Event. Research in Drama Education: The Journal of Applied Theatre and Performance, 10(2), 247-252.

Fisher M (2009) Capitalist Realism: Is There No Alternative? Winchester: Zed Books.

Foucault M (1980) Power/Knowledge: Selected Interviews and Other Writings, 1972-1977. Gordon C (ed.), trans. Marshall L, Mepham J, and Soper K. New York: Pantheon Books.

Foucault M (2005) The Hermeneutics of the Subject: Lectures at the Collège de France 1981-1982, trans. Burchell G. New York, NY: Picador.

Franks P and McAloon J (2016) Labour: The New Zealand Labour Party 1916-2016. Wellington: Victoria University Press.

Fraser S and Valentine K (2008) Substance and Substitution: Methadone Subjects in Liberal Societies. New York: Palgrave Macmillan.

Frisk L (2011) The Practice of Mindfulness: From Buddhist Practice to Secular Mainstream in a Postsecular Society. Paper given in Religion in Postsecular Society Åbo, Finland, 15-17 June.

Furness S and Gilligan P (2010) Religion, Belief and Social Work. Bristol: Policy Press.

Fuste-Forne F (2017) Building Experiencescapes in Christchurch. Landscape Review, 17, 44-57.

Galindez S (2012) Black Churches to Energize Occupy. The Indypendent. Available from www.indypendent.org/2012/01/09/black-churches-energize-occupy (last accessed 28/08/2015).

Ganiel G (2006) Emerging from Evangelical Subculture in Northern Ireland: An Analysis of Zero28 and Ikon Community. International Journal for the Study of the Christian Church, 6(1), 38-48.

Ganiel G and Marti G (2014) Northern Ireland, American and the Emerging Church Movement: Exploring the Significance of Peter Rollins and the Ikon Collective. Journal of the Irish Society for the Academic Study of Religions, 1(1), 26-47.

Gao J (2013) Deleuze's Concept of Desire. Deleuze Studies, 7(3), 406-420.

Gao Q, Qian J, and Yuan Z (2018) Multi-scaled Secularization or Postsecular present? Christianity and Migrant Workers in Shenzhen, China. Cultural Geographies, 25(4), 553-570.

Garbin D and Strhan A (2017) Religion and the Global City. London: Bloomsbury Publishing. 


\section{Bibliography}

Garrigan S (2010) The Real Peace Process: Worship, Politics and the End of Sectarianism. London: Equinox.

Garthwaite K (2016) Hunger Pains: Life Inside Foodbank Britain. Bristol: Policy Press.

Gibson-Graham JK (2006) A Postcapitalist Politics. Minneapolis, MN: University of Minnesota Press.

Gilbert J (2017) What is Acid Corbynism? Red Pepper. Available from www.redpepper. org.uk/what-is-acid-corbynism/ (last accessed 28/07/2018).

Gökarıksel B and Secor A (2014) The Veil, Desire, and the Gaze: Turning the Inside Out. Signs: Journal of Women in Culture and Society, 40(1), 177-200.

Gökarıksel B and Secor A (2015) Post-secular Geographies and the Problem of Pluralism: Religion and Everyday Life in Istanbul, Turkey. Political Geography, 46, 21-30.

Göle N (2010) The Civilizational, Spatial and Sexual Powers of the Secular. In Warner M, Vantantwerpen J, and Calhoun C (eds) Varieties of Secularism in a Secular Age. Cambridge, MA: Harvard University Press, pp. 243-264.

Gordon P (2011) What Hope Remains? The New Republic, 14 December. Available from https://newrepublic.com/article/98567/jurgen-habermas-religion-philosophy (last accessed 6 June 2017).

Gorski P and Altınordu A (2008) After Secularization? Annual Review of Sociology, 34, $55-85$.

Gorski P, Kim D, Torpey J, and Van Antwerpen J (eds) (2012) The Post-Secular in Question. New York: New York University Press.

Graham E (2013) Between a Rock and a Hard Place: Public Theology in a Postsecular Age. London: SCM Press.

Graham E (2018) How to Speak of God? Toward a Postsecular Apologetics. Practical Theology, 11(3), 206-217.

Graham E and Lowe S (2009) What Makes a Good City? Public Theology and the Urban Church. London: Darton, Longman and Todd.

Gray J (2010) Red Tory, By Phillip Blond. Independent. 2 April 2010. Available from www.independent.co.uk/arts-entertainment/books/reviews/red-tory-by-phillipblond-1933475.html (last accessed 08/06/18).

Greed C (1994) Women and Planning: Creating Gendered Realities. London: Routledge.

Greed C (2011) A Feminist Critique of the Postsecular City. In Beaumont J and Baker C (eds) Postsecular Cities: Space Theory and Practice. London and New York: Continuum, pp. 104-119.

Greeley AM (1966) After Secularity: The Neo-Gemeinschaft Society - A Post-Christian Postscript. Sociological Analysis, 27(3), 119-127.

Green E (2017) Evangelicals Are Bitterly Split Over Advising Trump. The Atlantic. 22 August 2017. Available from www.theatlantic.com/politics/archive/2017/08/ evangelical-advisers-trump/537513/ (last accessed 20/07/18).

Greenstreet W (2006) Past and Present Discourses. In Greenstreet W (ed.) Integrating Spirituality in Health and Social Care. Oxford: Radcliffe, pp. 20-31.

Gutiérrez G (1988) A Theology of Liberation: History, Politics, and Salvation. London: SCM Press.

Habermas J (1995) Reconciliation Through the Public Use of Reason: Remarks on John Rawls's Political Liberalism. The Journal of Philosophy, 92, 109-131.

Habermas J (2002) Religion and Rationality: Essays on Reason, God and Modernity. Cambridge, MA: MIT Press.

Habermas J (2005) Equal Treatment of Cultures and the Limits of Postmodern Liberalism. Journal of Political Philosophy, 13, 1-28. 
Habermas J (2006a) Religion in the Public Sphere. European Journal of Philosophy, $14(1), 1-25$.

Habermas J (2006b) Time of Transitions, trans. Schott G. Cambridge: Polity Press.

Habermas J (2006c) Pre-political Foundations of the Democratic Constitutional State? In Habermas J and Ratzinger J (eds) The Dialectics of Secularization: On Reason and Religion, trans. McNeil B. San Francisco: Ignatius, pp. 19-52.

Habermas J (2008) Notes on a Post-secular Society. Signandsight.com. 18 June 2008. 1-23. Available from www.signandsight.com/features/1714.html (last accessed 08/07/18).

Habermas J (2010) An Awareness of What is Missing. In Habermas J, Brieskorn N, Reder M, Ricken F, and Schmidt J (eds) An Awareness of What Is Missing: Faith and Reason in a Postsecular Age. Cambridge: Polity Press, pp. 15-23.

Habermas J (2010) An Awareness of What is Missing: Faith and Reason in a Post-secular Age. Cambridge: Polity Press.

Habermas J (2013) Reply to my Critics. In Calhoun C, Mendieta E, and VanAntwerpen J (eds) Habermas and Religion. Cambridge: Polity Press, pp. 347-390.

Habermas J and Ratzinger J (2006) The Dialectics of Secularization: On Reason and Religion. San Francisco, CA: Ignatius Press.

Hackworth J (2010) Compassionate Neoliberalism? Evangelical Christianity, the Welfare State, and the Politics of the Right. Studies in Political Economy, 86, 83-108.

Hackworth J (2012) Faith-Based: Religious Neoliberalism and the Politics of Welfare. Athens, GA: University of Georgia Press.

Häkli J and Kallio KP (2014) Subject, Action, and Polis: Theorizing Political Agency. Progress in Human Geography, 38(2), 181-200.

Hammond K and Richey J (eds) (2015) The Sage Returns: Confucian Revival in Contemporary China. Albany, NY: State University of New York.

Haraway D (2016) Staying With the Trouble: Making Kin in the Chthulucene. Durham, NC: Duke University Press.

Hardt M and Negri A (2001) Empire. Cambridge, MA: Harvard University Press.

Harrington A (2007) Habermas and the 'Post-Secular Society'. European Journal of Social Theory, 10(4), 543-560.

Harrison H (2011) Global Modernity, Local Community, and Spiritual Power in the Shanxi Catholic Church. In Chau A (ed.) Religion in Contemporary China: Revitalization and Innovation. London and New York: Routledge.

Harvey J (2011) Ecumenical Action in the Gorbals. Theology in Scotland, 13(2), 57-64.

Hastings A, Bailey N, Bramley G, and Gannon M (2017) Austerity Urbanism in England: The 'Regressive Redistribution' of Local Government Services and the Impact on the Poor and Marginalised. Environment and Planning A, 49(9), 2007-2024.

Hauerwas S (1983) The Peaceable Kingdom. Chicago, IL: University of Notre Dame Press.

Hauerwas S (2000) A Better Hope. Ada, MI: Brazos Press.

Hauerwas S and Coles R (2008) Christianity, Democracy and the Radical Ordinary. Eugene, OR: Cascade Books.

Hauerwas S, Wells S, Bretherton L., and Rook R (2010) Living Out Loud: Conversations About Virtue, Ethics and Evangelicalism. Milton Keyes: Paternoster.

Hayward B (2012) Canterbury's Political Quake. Available from www.stuff.co.nz/thepress/opinion/perspective/6664104/Canterburys-political-quake/ (last accessed 09/08/16).

Healy S (2013) Affective Dissent. Cosmopolitan Civil Societies Journal, 5(2), 114-130.

Heelas P and Woodhead L (2005) The Spiritual Revolution: Why Religion is Giving Way to Spirituality. Oxford: Blackwell. 
Hemming P (2011) Meaningful Encounters? Religion and Social Cohesion in the English Primary School. Social \& Cultural Geography, 12(1), 63-81.

Herman A, Beaumont J, Cloke P, and Walliser A (2012) Spaces of Postsecular Engagement in Cities. In Beaumont $\mathrm{J}$ and Cloke P (eds) Faith-based Organisations and Exclusion in European Cities. Bristol: Policy Press, pp. 59-80.

Hibbard S (2018) 'FGM has Stopped in Wales' but Women still 'Persecuted'. BBC News, 14 June 2018. Available from www.bbc.co.uk/news/uk-wales-44440167 (last accessed 30/10/18).

Hilgers M (2013) Embodying Neoliberalism: Thoughts and Responses to Critics. Social Anthropology, 21(1), 75-89.

Hitchins C (2008) God is not Great. London: Atlantic.

HM Treasury (2015) Spending Review and Autumn Statement 2015. London: HMSO. Available from www.gov.uk/government/uploads/system/uploads/attachment_data/ file/479749/52229_Blue_Book_PU1865_Web_Accessible.pdf (last accessed 20/06/18).

Holland J (2015) Peter Maurin's Ecological Lay New Monasticism: A Catholic Green Revolution Developing Rural Ecovillages, Urban Houses of Hospitality, \& EcoUniversities for a New Civilization. Washington, DC: Pacem in Terris Press.

Holloway J (2003) Make-Believe: Spiritual Practice, Embodiment and Sacred Space. Environment and Planning A, 35(11), 1961-1974.

Holloway J (2011) Tracing the Emergent in the Geographies of Religion and Belief. In Bailey A, Brace C, Carter S, Harvey D, Hill J, and Thomas N (eds) Emerging Geographies of Belief. Newcastle: Cambridge Scholars, pp. 30-53.

Holloway J (2011) Spiritual Life. In Del Casino VJ, Thomas ME, Cloke P, and Panelli R (eds) A Companion to Social Geography. Chichester: Blackwell Publishing Ltd, pp. 363-384.

Holloway J (2013) The Space that Faith Makes: Towards a (Hopeful) Ethos of Engagement. In Hopkins P, Kong L, and Olson E (eds) Religion and Place: Landscape, Politics and Piety. Dordrecht: Springer Publishing, pp. 203-218.

Holloway J and Valins O (2010) Editorial: Placing Religion and Spirituality in Geography. Social \& Cultural Geography, 3, 5-9.

Holton R (2011) Globalisation and the Nation-State. Basingstoke: Palgrave Macmillan, 2nd Edn.

Hooks B (1982) Ain't I a Woman?: Black Women and Feminism. London: Pluto Press.

Hopkins P (2017) Social Geography 1: Intersectionality. Progress in Human Geography doi.org/10.1177/0309132517743677.

Hopkins P, Kong L, and Olson E (eds) (2013) Religion and Place: Landscape, Politics and Piety. Dordrecht: Springer Publishing.

Horton J and Kraftl P (2009) Small Acts, Kind Words and 'Not Too Much Fuss': Implicit Activisms. Emotion, Space and Society, 2(1), 14-23, 1755-4586.

Housing Justice Homelessness Sunday Page: www.housingjustice.org.uk/Event/ homeless-Sunday-2018. (last accessed 16/05/16).

Howson C (2011) A Just Church: 21st Century Liberation Theology in Action. London: Continuum International Publishing Group.

Huffschmid A (2013) From Padre Mugica to Santa Muerte? Liberation Spirits and Religious Mutations in Urban Space in Latin America. In Becker J, Klingan K, Lanz S, and Wildner K (eds) Global Prayers: Contemporary Manifestations of the Religious in the City. Baden: Lars Müller Publishers, pp. 392-407.

Inbar Y, Pizzaro D, and Bloom P (2011) Conservatives are More Easily Disgusted than Liberals. Cognition and Emotion, 23, 714-725. 
Isin EF and Rygiel K (2007) Abject Extrality: Frontiers, Zones and Camps. In Dauphinee $\mathrm{E}$ and Masters C (eds) The Logics of Biopower and the War on Terror: Living, Dying, Surviving. Basingstoke: Palgrave Macmillan, pp. 181-203.

Ivinson G and Renold E (2013) Subjectivity, Affect and Place: Thinking with Deleuze and Guattari's Body without Organs $(\mathrm{BwO})$ to Explore a Young Girl's Becomings in a Post-industrial Locale. Subjectivity, 6(4), 369-390.

Jabir T (2015) Secularism, 'Indian secularism' and Post-secular Discourses in India. Available from www.cedl.ac.in/download.php?id=25 (last accessed 25/05/18).

Jaffrelot C (1999) The Hindu National Movement and Indian Politics: 1925 to the 1990s. With New Afterword. New Delhi: Penguin Books.

James M (2014) A Brief History of Seven Killings. London: Oneworld Publications.

Jamoul L and Wills J (2008) Faith in Politics. Urban Studies, 45(10), 2035-2056.

Jedan, C (2010) Beyond the Secular? Public Reason and the Search for a Concept of Postsecular Legitimacy. In Molendijk A, Beaumont J, and Jedan C (eds) Exploring the Postsecular: The Religious, the Political and the Urban. Leiden, the Netherlands: Brill, pp. 311-327.

Jenkins J (2017) Meet the Clergy who Stared Down White Supremacists in Charlottesville. Think Progress. Available from https://thinkprogress.org/clergy-in-charlottesvillee95752415c3e/ (last accessed 20/07/18).

Jensen D (2006) Endgame: Vol. II, Resistance. New York: Seven Stories Press.

Jensen T (2011) On the Emotional Terrain of Neoliberalism. Journal of Aesthetics and Protest, 8. Available from http://joaap.org/issue8/jensen.htm (last accessed 07/07/18).

Ji Z (2006) Non-Institutional Religious Re-Composition among the Chinese Youth. Social Compass, 53, 535-549.

Joas H (2008) Do We Need Religion? On the Experience of Self-transcendence, trans. Skinner A. Boulder, CO: Paradigm Publishers.

Johansson M and Kociatkiewicz J (2011) City Festivals: Creativity and Control in Staged Urban Experiences. European Urban and Regional Studies, 18, 392-405.

Jones R (2008) Progressive \& Religious: How Christian, Jewish, Muslim, and Buddhist Leaders are Moving Beyond Partisan Politics and Transforming American Public Life. Michigan: Rowman \& Littlefield Publishers.

Jones R and Heley J (2016) Post-pastoral? Rethinking Religion and the Reconstruction of Rural Space. Journal of Rural Studies, 45, 15-23.

Judson Memorial Church Homepage: www.judson.org/index.php (last accessed 30/09/16).

Juergensmeyer M, Griego D, and Soboslai J (2015) God in the Tumult of the Global Square. Oakland, CA: University of California Press.

Juris JS (2005) Social Forums and the Margins: Networking Logics and the Cultural Politics of Autonomous Spaces. Ephemera, 5(2), 253-272.

Karpov V (2010) Desecularisation: A Conceptual Framework. Journal of Church and State, 52, 232-270.

Karpov V (2013) The Social Dynamics of Russia's Desecularisation: A Comparative and Theoretical Perspective. Religion, State and Society, 41, 254-283.

Kaufmann (2009) Locating the Postsecular. Religion \& Literature, 41(3), 68-73.

Kearney R (2011) Anatheism: Returning to God After God. New York: Columbia University Press.

Kershaw B (1992) The Politics of Performance: Radical Theatre as Cultural Intervention. London: Routledge.

Kessler E and Arkush M (2008) Keeping Faith in Development: The Significance of Interfaith Relations in the Work of Humanitarian Aid and International Development Organisations. Cambridge: Woolf Institute. 


\section{Bibliography}

Khanum F (2012) A Common Agenda: Interfaith Dialogue and Faith Secular Partnership. Paper in Africa-UK Annual Conference 2012: Faith and Development in Africa. 3 December 2012. Chelsea Old Town Hall, King's Road, London.

Kidd SA (2009) 'A Lot of Us Look at Life Differently': Homeless Youths and Art on the Outside. Cultural Studies-Critical Methodologies, 9(2), 345-367.

Kimberly J, Troy S, Glover D, and Parry DC (2004) Leisure Spaces as Potential Sites for Interracial Interaction: Community Gardens in Urban Areas. Journal of Leisure Research, 36(3), 336-355.

King N (2016) No Borders - The Politics of Immigration Control and Resistance. London: Zed Books.

Klein N (2017) No Is Not Enough: Defeating the New Shock Politics. London: Allen Lane.

Kong L (2010) Global Shifts, Theoretical Shifts: Changing Geographies of Religion. Progress in Human Geography, 34(6), 755-776.

Kuhn R (1976) The Demon of Noontide: Ennui in Western Literature. Princeton, NJ: Princeton University Press.

Kumar P (2008) Limiting Secularism: The Ethics of Co-existence in Indian Literature and Film. Minneapolis: Minnesota University Press.

Kumm B (2013) Finding Healing through Songwriting: A Song for Nicolette. International Journal of Community Music, 6(2), 205-217.

Kuznetsova I and Round J (2014) Communities and Social Care in Russia: The Role of Muslim Welfare Provision in Everyday Life in Russia's Tartarstan Region. International Social Work, 57, 486-496.

Lafonte C (2007) Religion in the Public Sphere: Remarks on Habermas's Conception of Public Deliberation in Postsecular Societies. Constellations, 14, 239-259.

Lambie-Mumford H (2017) Hungry Britain: The Rise of Food Charity. Bristol: Policy Press.

Lancione M (2014) Entanglements of Faith: Discourses, Practices of Care and Homeless People in an Italian City of Saints. Urban Studies, 51, 3062-3078.

Landy J and Saler M (eds) (2009) The Re-enchantment of the World. Stanford, CA: Stanford University Press.

Lane BC (2002) Landscapes of the Sacred: Geography and Narrative in American Spirituality. Baltimore, MD: The Johns Hopkins University Press.

Larner W (2000) Neo-liberalism Policy, Ideology, Governmentality. Studies in Political Economy, 63(1), 5-25.

Latour B (1993) We Have Never Been Modern, trans. C Porter. Cambridge, MA: Harvard University Press.

Latour B (2005) Reassembling the Social. Oxford: Oxford University Press.

Lawson V (2007) Geographies of Care and Responsibility. Annals of the Association of American Geographers, 97, 1-11.

Lawson V and Elwood S (2013) Encountering Poverty: Space, Class, and Poverty Politics. Antipode, 46(1), 209-228.

Lee L (2015) Recognizing the Non-religious: Reimagining the Secular. Oxford: Oxford University Press.

Lee L (2017) Godlessness in the Global City. In Garbin D and Strhan A (eds) Religion and the Global City. London: Bloomsbury Publishing, pp. 135-152.

Levinas E (1978) Existence and Existents, trans. Lingis A. The Hague: M. Nijhoff.

Levine G (2008) Darwin Loves You: Natural Selection and the Re-enchantment of the World. Princeton, NJ: Princeton University Press. 
Lewicki A and O'Toole T (2016) Acts and Practices of Citizenship: Muslim Women's Activism in the UK. Ethnic and Racial Studies, 40, 152-171.

Lewis T (2016) Spirited Publics? Post-secularism, Enchantment and Enterprise on Indian Television. In Marshall P, D'Cruz G, McDonald S, and Lee K. (eds) Contemporary Publics. London: Palgrave Macmillan.

Ley D (2011) Preface: Towards a Postsecular City? In Beaumont J and Baker C (eds) Postsecular Cities: Space, Theory and Practice. London: Continuum, pp. xii-xiv.

Ley D and Tse J (2013) Homo Religiosus? Religion and Immigrant Subjectivities. In Hopkins P, Kong L, and Olson E (eds) Religion and Place: Landscape, Politics and Piety. New York: Springer, pp. 149-166.

Lidman L (2014) In Uganda, Coffee Co-op Blends Jewish, Muslim and Christian Farmers. The Times of Israel. Available from www.timesofisrael.com/in-ugandacoffee-co-op-blends-jewish-muslim-and-christian-farmers/ (last accessed 27/07/18).

Lineham P (2017) Sunday Best: How Religion Shaped New Zealand and How New Zealand Shaped Religion. Palmerston North: Massey University Press.

Lonergan G, Lewis H, Tomalin E, and Waite L (forthcoming) Professionalisation or Secularisation? Understanding Postsecular Faith-based Anti-trafficking Responses. Current Sociology.

Lordon F (2014) Willing Slaves of Capital: Spinoza and Marx on Desire, trans. Ash G. London: Verso ebook version.

Luckmann T (1967) The Invisible Religion: The Problem of Religion in Modern Society. New York: The Macmillan Company.

Luz N (2013) Metaphors to Live by: Identity Formation and Resistance Among Minority Muslims in Israel. In Hopkins P, Kong L, and Olson E (eds) Religion and Place: Landscape, Politics, and Piety. New York, NY: Springer, pp. 57-74.

Lyons S (2014) The Disenchantment/Re-enchantment of the World. Modern Language Review, 109, 873-885.

MacDonald F (2002) Towards a Spatial Theory of Worship: Some Observations from Presbyterian Scotland. Social \& Cultural Geography, 3(1), 61-80.

Madan TN (1997) Modern Myths, Locked Minds: Secularism and Fundamentalism in India. New Delhi: Oxford University Press.

Madan TN (2011) Sociological Traditions: Methods and Perspectives in the Sociology of India. New Delhi: Sage.

Madsen R (1998) China's Catholics: Tragedy and Hope in an Emerging Civil Society. California: Berkeley University of California.

Mahmood S (2005) The Politics of Piety: The Islamic Revival and the Feminist Subject. Princeton, NJ: Princeton University Press.

Mahmood S (2009) Religious Reason and Secular Affect: An Incommensurable Divide? Critical Inquiry, 35(4), 836-862.

Malik AR (2007) Take Me to Your Leader: Post-secular Society and the Islam Industry. Eurozine 23 April.

Malpass A, Cloke P, Barnett C, and Clarke N (2007) Fairtrade Urbanism? The Politics of Place Beyond Place in the Bristol Fairtrade City Campaign. International Journal of Urban and Regional Research, 31, 653-645.

Maoz I (2004) Peace Building in Violent Conflict: Israeli-Palestinian Post-Oslo Peopleto-People Activities. International Journal of Politics, Culture, and Society, 17(3), $563-574$.

Marsh C (2003) The Beloved Community: How Faith Shapes Social Justice, From the Civil Rights Movement to Today. New York: Basic Books. 


\section{Bibliography}

Martin D (1969) Notes for a General Theory of Secularisation. European Journal of Sociology, 10(2), 192-201.

Martin D (2011) The Future of Christianity. London: Routledge.

Martinson M (2013) Cultural Materiality and Spiritual Alienation. Political Theology, $14(2), 219-234$.

Massey D (2004) Geographies of Responsibility. Geografiska Annaler B, 86, 5-18.

Massey D (2008) Geographies of Solidarities. In Clark N, Massey D, and Sarre P (eds) Material Geographies: A World in the Making. London: SAGE/Open University Press, pp. 311-362.

Massumi B (1997) The Political Economy of Belonging and the Logic of Relation. In Davidson C (ed.) Anybody. Cambridge, MA: MIT Press, pp. 224-238.

Mavelli L (2012) Postsecular Resistance, the Body, and the 2011 Egyptian Revolution. Review of International Studies, 38(5), 1057-1078.

Mavelli L and Petito F (2012) The Postsecular in International Relations: An Overview. Review of International Studies, 38(5), 931-942.

Mavelli L and Wilson E (2016) Postsecularism and International Relations. In Haynes J (ed.) Routledge Handbook of Religion and Politics. New York and London: Routledge, pp. 251-269.

May G (2018) Can Radical Hospitality be too Radical? Available from https://radio public.com/nomad-podcast-8Q20Pr/ep/s1!ae8. (last accessed 07/06/18).

May J and Cloke P (2014) Modes of Attentiveness: Reading for Difference in Geographies of Homelessness. Antipode, 46, 894-920.

May J, Cloke P, and Johnsen S (2006) Shelter at the Margins: New Labour and the Changing State of Emergency Accommodation for Single Homeless People in Britain. Policy and Politics, 34, 711-730.

McBroome K (2013) Revolutionaries: The Women of the Egyptian Uprising. Pace University (unpublished thesis). Available from www.pace.edu/sites/default/files/files/ thesis-kerry-mcbroome.pdf (last accessed 25/05/18).

McCarraher E (2005) The Enchantments of Mammon: Notes Towards a Theological History of Capitalism. Modern Theology, 21(3), 429-461.

McClish C (2009) Activism Based in Embarrassment: The Anti-consumption Spirituality of the Reverend Billy. Liminalities, 5(2), 1-20.

McConnell M (2007) Secular Reason and the Misguided Attempt to Exclude Religious Argument from Democratic Deliberation. Journal of Law, Philosophy and Culture, 1, 159-174.

McCormack DP (2014) Refrains for Moving Bodies: Experience and Experiment in Affective Spaces. Durham, NC: Duke University Press.

McCowan T (2017) Building Bridges Rather than Walls: Research into an Experiential Model of Interfaith Education in Secondary Schools. British Journal of Religious Education, 39(3), 269-278.

McDonald C and Marston G (2005) Workfare as Welfare: Governing Unemployment in the Advanced Liberal State. Critical Social Policy, 25, 374-400.

McDonald K (2002) From Solidarity to Fluidarity: Social Movements Beyond 'Collective Identity' - The Case of Globalization Conflicts. Social Movement Studies. Journal of Social, Cultural and Political Protest, 1(2), 109-128.

McFarlane C (2011) Learning the City: Knowledge and Translocal Assemblage. Oxford: Wiley-Blackwell.

McGlynn C, Niens U, Cairns E, and Hewstone M (2004) Moving out of Conflict: The Contribution of Integrated Schools in Northern Ireland to Identity, Attitudes, Forgiveness and Reconciliation. Journal of Peace Education, 1(2), 147-163. 
McIntosh A and Carmichael M (2016) Spiritual Activism: Leadership as Service. Cambridge: Green Books.

McKanan D (2011) Prophetic Encounters: Religion and the American Radical Tradition. Boston, MA: Beacon.

McLennan G (2007) Towards Postsecular Sociology? Sociology, 41, 857-870.

McLennan G (2010) The Postsecular Turn. Theory, Culture and Society, 27, 3-20.

McLennan G (2011) Postsecular Cities and Radical Critique: A Philosophical Seachange? In Beaumont $\mathrm{J}$ and Baker $\mathrm{C}$ (eds) Postsecular Cities: space, theory and practice. London: Continuum, pp. 15-30.

Megoran N (2010) Towards a Geography of Peace: Pacific Geopolitics and Evangelical Christian Crusade Apologies. Transactions of the Institute of British Geographers, 35(3), 382-398.

Megoran N (2013) Radical Politics and the Apocalypse: Activist Readings of Revelation. Area, 45(2), 141-147.

Melucci A (1996) Challenging Codes: Collective Action in the Information Age. Cambridge: Cambridge University Press.

Mendieta E (2010) A Postsecular World Society? On the Philosophical Significance of Postsecular Consciousness and the Multicultural World Society. Interview with Jurgen Habermas. Monthly Review, 21 March. Available from http://mrzine.monthlyreview. org/21010/habermas210310.html (last accessed 06/06/17).

Menon N (2007) Living with Secularism. In Needham A and Rajan R (eds) The Crisis of Secularism in India. Durham, NC: Duke University Press.

Mentinis M (2014) Towards a Revolutionary Psychology: On the Vicennial of the Zapatista Insurrection. The Occupied Times. Available from http://theoccupiedtimes. org/? $\mathrm{p}=12837$ (last accessed 12/04/18).

Meyer B (2013) Lessons from 'Global Prayers': How Religion Takes Places in the City. In Becker J, Klingan K, Lanz S, and Wildner K (eds) Global Prayers: Contemporary Manifestations of the Religious in the City. Baden: Lars Muller Publishers, pp. 590-601.

Meyer F and Miggelbrink J (2017) Post-secular Rapprochement in Peripheralized Regions - Politics of Withdrawal and Parish Community Responses. Geogr. Helv, 72, 361-370.

Milbank J (1990) Theology and Social Theory: Beyond Secular Reason. Malden, MA: Blackwell.

Milbank J (1995) Only Theology Overcomes Metaphysics. New Blackfriars, 76(895), $325-343$.

Milbank J (2005) Materialism and Transcendence. In Davis C, Milbank J, and Zizek S (eds) Theology and the Political: New Debates. Durham, NC: Duke University Press, pp. 393-426.

Milbank J (2006) Theology and Social Theory: Beyond Secular Reason. Oxford: WileyBlackwell, 2nd Edn.

Milbank J (N.D.) What is Radical Orthodoxy? Available from www.unifr.ch/theo/assets/ files/SA2015/Theses_EN.pdf (last accessed 20/09/17).

Milbank J, Pickstock C, and Ward G (eds) (1999) Radical Orthodoxy. London: Routledge.

Mindock C (2017) Trump's Travel Ban on Six Muslim-majority Countries to be Fully Enacted after Supreme Court Ruling. Available from www.independent.co.uk/news/ world/america/us-politics/trump-travel-ban-muslim-countries-supreme-court-rulingallowed-go-ahead-latest-a8092086.html. (last accessed 15/05/2018).

Mitchell B (2017) Faith Based Development. Maryknoll, NY: Orbis. 


\section{Bibliography}

Mitchell D (1997) The Annihilation of Space by Law: The Roots and Implications of Anti-homeless Laws in the United States. Antipode, 29(3), 303-335.

Modood T (2005) Multicultural Politics: Racism, Ethnicity and Muslims in Britain. Edinburgh: Edinburgh University Press.

Moghadam V (1995) Gender and Revolutionary Transformation: Iran 1979 and East Central Europe 1989. Gender and Society, 9, 328-358.

Molendijk A, Beaumont J, and Jedan C (eds) (2010) Exploring the Postsecular: The Religious, the Political and the Urban. Leiden: Brill.

Monaghan M (2012) The Recent Evolution of UK Drug Strategies: From Maintenance to Behaviour Change? People, Place \& Policy Online, 6, 29-40.

Monbiot G (2017) Out of the Wreckage: A New Politics for an Age of Crisis. New York: Verso Books.

Moody KS (2010) 'I Hate Your Church; What I Want is My Kingdom': Emerging Spiritualities in the UK Emerging Church Milieu. The Expository Times, 121(10), 405-503.

Moody KS (2012) Retrospective Speculative Philosophy: Looking for Traces of Žižek's Communist Collective in Emerging Christian Praxis. Political Theology, 13(2), 183-199.

Muehlebach A (2012) The Moral Neoliberal: Welfare and Citizenship in Italy. Chicago: University of Chicago Press.

Mufti A (2013) Part 1: Why I Am Not a Postsecularist. Boundary 2: An International Journal of Literature and Culture, 40(1), 7-19.

Murphy S (2009) 'Compassionate' Strategies of Managing Homelessness: Post-revanchist Geographies in San Francisco. Antipode, 41(2), 305-325.

Murray S (2011) Post-Christendom: Church and Mission in a Strange New World. Milton Keynes: Paternoster Press.

Nancy JL (1994) Cut Throat Sun. In Arteaga A (ed.) An Other Tongue: Nation and Ethnicity in the Linguistic Borderlands. Durham, NC: Duke University Press, p. 113.

Nandy A (1997) Twilight of Certitudes: Secularism, Hindu Nationalism and Other Masks of Deculturation. Alternatives, 22(2), 157-176.

Narayanan Y (ed.) Religion and Urbanism: Reconceptualising Sustainable Cities for South Asia. London and New York: Routledge.

$\mathrm{Ng}$ and Fulda (2017) Religious Dimensions of Hong Kong's Umbrella Movement. Journal of Church and State, 1-21. https://doi.org/10.1093/jes/csx053.

Nietzsche F (1974) The Gay Science, trans. Kauffmann W. New York, NY: Vintage.

Nita M (2014) Christian and Muslim Climate Activists Fasting and Praying for the Planet: Emotional Translation of 'Dark Green' Activism and Green-Faith Identities. In GlobusVeldman R, Szasz A, and Haluza-DeLay R (eds) How the World's Religions are Responding to Climate Change Social Scientific Investigation. New York: Routledge, pp. 229-243.

Norris P and Inglehart R (2004) Sacred and Secular: Religion and Politics Worldwide. Cambridge: Cambridge University Press.

Noxolo P, Raghuram P, and Madge C (2012) Unsettling Responsibility: Postcolonial Interventions. Transactions of the Institute of British Geographers, 37, 418-429.

Nusseibeh L (2011) Women and Power in the Israeli-Palestinian Conflict. PalestineIsrael: A Journal of Politics, Economics and Culture, 17(3-4). Available from www. pij.org/details.php?id=1371 (last accessed 27/07/18).

Nynas P, Lassander M, and Utriainen T (eds) (2015) Post-secular Society. New Brunswick, NJ: Transaction.

O’Neill K (2014) On Liberation: Crack, Christianity, and Captivity in Postwar Guatemala City. Social Text, 32, 11-28. 
O'Neill S (2000) The Politics of Inclusive Agreements: Towards a Critical Discourse Theory of Democracy. Political Studies, 48, 503-521.

Olson E (2016) Geography and Ethics II: Emotions and Morality. Progress in Human Geography, 40(6), 830-838.

Olson E, Hopkins P, Pain R, and Vincent G (2013) Retheorizing the Postsecular Present: Embodiment, Spatial Transcendence, and Challenges to Authenticity Among Young Christians in Glasgow, Scotland. Annals of the Association of American Geographers, 103, 1421-1436.

Olson K (2005) Music for Community Education and Emancipatory Learning. New Directions for Adult and Continuing Education, 107(Autumn), 55-64.

Ong A (2007) Neoliberalism as a Mobile Technology. Transaction of the Institute of British Geographers, 32(1), 3-8.

Osuri G (2012) (Post) Secular Discomforts: Religio-Secular Disclosures in the Indian Context. Cultural Studies Review, 18, 32-51.

Özyürek E (2006) The Nostalgia for the Modern: State Secularism and Everyday Politics in Turkey. Raleigh: Duke University Press.

Pacione M (1999) The Relevance of Religion for a Relevant Human Geography. Scottish Geographical Journal, 115, 117-131.

Parish S (1997) Goddesses Dancing in the City: Hinduism in an Urban Incarnation - A Review Article. International Journal of Hindu Studies, 1, 441-484.

Parsons M (2014) Rubble to Resurrection: Churches Respond in the Canterbury Quakes. Auckland: Daystar.

Phelps H (2013) Resonating Moral Monday. Political Theology Network 11 July 2013. Available from www.politicaltheology.com/blog/resonating-moral-monday/ (last accessed 22/07/18).

Pickerill J and Chatterton P (2006) Notes Towards Autonomous Geographies: Creation, Resistance and Self-management as Survival tactics. Progress in Human Geography, 30(6), 730-746.

Pickles K (2016) Christchurch Ruptures. Auckland: Bridget Williams Books.

Pierson M (2012) The Art of Curating Worship. London: Canterbury Press Norwich.

Plender A (2018) After Grenfell: The Faith Groups' Response. Theos Report: London. Available from www.theosthinktank.co.uk/research/2018/06/01/after-grenfell-thefaith-groups-response (last accessed 20/07/18).

Pollard J and Samers M (2007) Islamic Banking and Finance: Postcolonial Political Economy and the Decentring of Economic Geography. Transactions of the Institute of British Geographers, 32, 313-330.

Polletta F and Jasper JM (2001) Collective Identity and Social Movements. Annual Review of Sociology, 27, 283-305.

Popke J (2007) Geography and Ethics: Spaces of Cosmopolitan Responsibility. Progress in Human Geography, 31, 509-518.

Popke J (2009) Ethical Spaces of Being In-common. In Smith S, Pain R, Marston S, and Jones III J-P (eds) Handbook of Social Geography. London: Sage, pp. 435-454.

Possamai A (2017) The i-zation of Society, Religion, and Neoliberal Post-Secularisation. Basingstoke: Palgrave Macmillan.

Potter P (2003) Belief in Control: Regulation of Religion in China. The China Quarterly, 174, 338-358.

Powell H (2004) A Dream Wedding: From Community Music to Music Therapy with a Community. In Pavlicevic M and Ansdell G (eds) Community Music Therapy. London: Jessica Kingsley Publishers, pp. 167-185. 


\section{Bibliography}

Prior J and Crofts P (2015) Shooting Up Illicit Drugs with God and the State: The Legalspatial Constitution of Sydney's Medically Supervised Injecting Centre as a Sanctuary. Geographical Research, 54(3), 313-323.

Prochaska F (2006) Christianity and Social Service in Modern Britain. Oxford: Oxford University Press.

Qian J and Kong L (2018) Buddhism Co. Ltd? Epistemology of Religiosity, and the Reinvention of a Buddhist Monastery in Hong Kong. Environment and Planning D Society and Space, 36, 159-177.

Radden J (ed.) (2000) The Nature of Melancholy: From Aristotle to Kristeva. Oxford: Oxford University Press.

Rashbrooke M (ed.) (2013) Inequality: A NZ Crisis. Auckland: Bridget Williams Books.

Rashkover R (2017) Covenantal Ethics and the 2016 Election. Political Theology, 18(3), 201-205.

Ratti M (2013) The Postsecular Imagination: Postcolonialism, Religion and Literature. London and New York: Routledge.

Rawls J (1995) Political Liberalism: A Reply to Habermas. Journal of Philosophy, 92, 132-180.

Rawls J (1997) The Idea of Public Reason Revisited. The University of Chicago Law Review, 64, 765-807.

Rawls J (2005) Political Liberalism: Expanded Edition. New York: Columbia University Press.

Reder M and Schmidt J (2010) Habermas and Religion. In Habermas J, Brieskorn N, Reder M, Ricken F, and Schmidt J (eds) An Awareness of What is Missing: Faith and Reason in a Post-Secular Age. Cambridge: Polity Press, pp. 1-14.

Reinhard K (2005) Toward a Political Theory of the Neighbour. In Zizek S, Santner E, and Reinhard K (eds) The Neighbor: Three Inquiries on Political Theology. Chicago, IL: University of Chicago Press, pp. 11-75.

Reuver M (1988) Christians as Peacemakers: Peace Movements in Europe and the USA. Geneva: WCC Publications.

Reynolds R (2014) Desire for the Gap. In Bennett B, Dann J, Johnson E, and Reynolds R (eds) Once In A Lifetime: City-building After Disaster in Christchurch. Christchurch: Freerange Press, pp. 167-176.

Richardson E (2013) Using Performance in Human Geography: Conditions and Possibilities. Kaleidoscope: The Interdisciplinary Postgraduate Journal of Durham University's Institute of Advanced Study, 5(1), 124-133.

Rieger J (2001) God and the Excluded: Visions and Blindspots in Contemporary Theology. Minneapolis: Fortress.

Rieger J (2012) Power or Glory? Available from http://aeon.co/magazine/society/joergrieger-occupy-religion/ (last accessed 28/08/15).

Rieger J and Pui-lan K (2012) Occupy Religion: Theology of the Multitude. Plymouth: Rowman \& Littlefield Publishers, Inc.

Riesebrodt M (2014) Religion in the Modern World: Between Secularization and Resurgence. European University Institute Max Weber Programme. Available from http:// cadmus.eui.eu/bitstream/handle/1814/29698/MWP_LS_2014_01_Riesebrodt.pdf (last accessed 26/05/18).

Roberts JD (2005) Bonhoeffer \& King: Speaking Truth to Power. Louisville, KY: Westminster John Knox Press.

Rodriguez T (2010) Bio-pistis: Conversion of Heroin Addicts in Prisons, On Medicine, 
and with God. In Adkins J, Occhipinti L, and Hefferan T (eds) Not by Faith Alone: Social Services, Social Justice, and Faith-based Organizations in the United States. Lanham, MD: Lexington Books, Rowman \& Littlefield, pp. 207-230.

Roe G (2005) Harm Reduction as Paradigm: Is Better Than Bad Good Enough? The Origins of Harm Reduction. Critical Public Health, 15(3), 243-250.

Rohr R (2003) Everything Belongs: The Gift of Contemplative Prayer. New York, NY: The Crossroad Publishing Company.

Rollins P (2006) How (Not) to Speak of God. London: SPCK.

Romanillos J, Beaumont J, and Sen M (2012) State-religion Relations and Welfare Regimes in Europe. In Beaumont $\mathrm{J}$ and Cloke P (eds) Faith-based Organizations and Exclusion in European Cities. Bristol: Policy Press, pp. 37-58.

Roome D (2012) Christchurch Earthquake Images. Wellington: Awa Press.

Rose G (1997) Situating Knowledges: Positionality, Reflexivities and Other Tactics. Progress in Human Geography, 21(3), 305-320.

Rose M (2017) Machines of Loving Grace: Angels, Cyborgs, and Postsecular Labour. Journal for Cultural and Religious Theory, 16(2), 240-259.

Routledge P (2003) Convergence Space: Process Geographies of Grassroots Globalization Networks. Transactions of the Institute of British Geographers, 28(3), 333-349.

Ruud E (2004) Foreword: Reclaiming Music. In Pavlicevic M and Ansdell G (eds) Community Music Therapy. London: Jessica Kingsley Publishers, pp. 11-14.

Rygiel K (2011) Bordering Solidarities: Migrant Activism and the Politics of Movement and Camps at Calais. Citizenship Studies, 15(1), 1-19.

Saler A (2011) As If: Modern Enchantment and the Literary Prehistory of Virtual History. Oxford: Oxford University Press.

Salter M (2013) Carl Schmitt on the Secularisation of Religious Texts as a Resacralisation of Jurisprudence? International Journal for the Semiotics of Law, 26, 113-147.

Sandel M (2012) What Money Can't Buy: The Moral Limits of Markets. London: Allen Lane.

Sandri E (2018) 'Volunteer Humanitarianism': Volunteers and Humanitarian Aid in the Jungle Refugee Camp of Calais. Journal of Ethnic and Migration Studies, 44(1), $65-80$.

Sartre JP (2003) Being and Nothingness: An Essay on Phenomenological Ontology. London: Routledge.

Sayer A (2015) Why We Can't Afford the Rich. Bristol: Policy Press.

Schaper D (2016) Sanctuary Movement Sees Post-election Resurgence. Here's How to Get Involved. Available from https://sojo.net/articles/sanctuary-movement-sees-postelection-resurgence-heres-how-get-involved (last accessed 15/05/18).

Schmitt C (2005) [1922] Schmitt, Political Theology, Four Chapters on the Concept of Sovereignty, trans. Schwab G. Chicago: University of Chicago Press.

Schumaker J (2016) The Demoralized Mind. The New Internationalist. April 2016. Available from https://newint.org/columns/essays/2016/04/01/psycho-spiritual-crisis (last accessed 10/11/17).

Sen A (2005) Secularism and Its Discontents. The Argumentative Indian: Writings on Indian History, Culture and Identity. London: Penguin Books, pp. 294-316.

Sherwood H (2016) Hundreds of Churches Offer Sanctuary to Undocumented Migrants after Election. Guardian. 27 November 2016. Available from www.theguardian.com/ us-news/2016/nov/27/undocumented-immigrations-us-churches-sanctuarytrump?CMP=share_btn_link (last accessed 15/05/18).

Sherwood H (2017) Grenfell: Faith Groups Step in to Mediate Between Officials and 
Community. Guardian. 19 July 2017. Available from www.theguardian.com/uknews/2017/jul/19/grenfell-faith-groups-step-in-to-mediate-between-officials-andcommunity (last accessed 21/07/18).

Shildrick T (2018) Lessons from Grenfell: Poverty Propaganda, Stigma and Class Power. The Sociological Review Monographs, 66(4), 783-798.

Shortall H (2015) Nine Things I Learned Volunteering in a Refugee Camp. 13 October 2015. Available from https://hollyshortall.wordpress.com/2015/10/13/nine-things-ilearned-volunteering-in-a-refugee-camp/ (last accessed 21/07/18).

Sibley C and Bulbulia J (2012) Faith after an Earthquake. A Longitudinal Study of Religion and Perceived Health Before and After the 2011 Christchurch New Zealand Earthquake. PLoS ONE, 7(12): e49648. Available from https://doi.org/10.1371/journal. pone.0049648 (last accessed 29/03/18).

Simmel G (2002) [1903] The Metropolis and Mental Life. In Bridge G and Watson S (eds) The Blackwell City Reader. Oxford and Malden, MA: Wiley-Blackwell, pp. 11-19.

Simpson P (2017) Spacing the Subject: Thinking Subjectivity after Non-representational Theory. Geography Compass, 10.1111/gec3.12347.

Sitrin M (2006) Horizontalism: Voices of Popular Power in Argentina. Oakland: AK Press.

Sitrin M (2012) Everyday Revolutions: Horizontalism and Autonomy in Argentina. New York and London: Zed.

Slater T (2014) The Myth of 'Broken Britain': Welfare Reform and the Production of Ignorance. Antipode, 46(4), 948-969.

Slessarev-Jamir H (2011) Prophetic Activism: Progressive Religious Justice Movements in Contemporary America. New York and London: New York University Press.

Smith C (1996) Disruptive Religion: The Force of Faith in Social Movement Activism. London: Routledge.

Smith C (2016) Addiction, Modernity, and the City: A Users' Guide to Urban Space. London: Routledge.

Smith D (2000) Moral Geographies: Ethics in a World of Difference. Edinburgh: Edinburgh University Press.

Smith N (1992) Contours of a Spatialized Politics: Homeless Vehicles and the Production of Geographical Scale. Social Text, 33, 54-81.

Smith TA, Murrey A, and Leck H (2017) 'What Kind of Witchcraft is This?' Development, Magic and Spiritual Ontologies. Third World Thematics, 2(2-3), 141-156.

Snow DA and Anderson L (1993) Down on Their Luck: A Study of Homeless Street People. Berkeley: University of California Press.

Sojourners Website. We the People Cannot Be Silent. Available from https://sojo.net/ media/we-people-cannot-be-silent (last accessed 15/05/18).

Solnit R (2009) A Paradise Built in Hell: The Extraordinary Communities that Arise in Disaster. New York: Viking Penguin.

Southern N (2011) Strong Religion and Political Viewpoints in a Deeply Divided Society: An Examination of the Gospel Hall Tradition in Northern Ireland. Journal of Contemporary Religion, 26(3), 433-449.

Sparke M (2013) From Global Dispossession to Local Repossession: Towards a Worldly Cultural Geography of Occupy Activism. In Johnson N, Schein R, and Winders J (eds) Companion to Cultural Geography. Oxford: Wiley-Blackwell, pp. 167-185.

Spivak G (2004) Terror: A Speech After 9-11. Boundary, 31, 81-111.

Squire V (2011) From Community Cohesion to Mobile Solidarities: The City of Sanctuary Network and the Strangers into Citizens Campaign. Political Studies, 59, 290-307. 
Stacey T (2017) Imagining Solidarity in the Twenty-first Century: Towards a Performative Postsecularism. Religion, State and Society, 45(2), 141-158.

Staeheli LA (2013) THE 2011 ANTIPODE AAG LECTURE - Whose Responsibility Is It? Obligation, Citizenship and Social Welfare. Antipode, 45(3), 521-540.

Stark R and Finke R (2000) Acts of Faith: Explaining the Human Side of Religion. Berkeley: University of California Press.

Stepan A (2011) The Multiple Secularisms of Modern Democratic and Non-Democratic Regimes. In Calhoun C, Juergensmeyer M, and VanAntwerpen J (eds) Rethinking Secularism. Oxford: Oxford University Press.

Storper M and Scott A (2016) Current Debates in Urban Theory: A Critical Assessment. Urban Studies, 53, 1114-1136.

Stout J (2004) Democracy and Tradition. Princeton, NJ: Princeton University Press.

Sullivan S (2005) An Other World is Possible? On Representation, Rationalism and Romanticism in Social Forum. Ephemera, 5(2), 370-392.

Suter K (2008) The Future of the Nation-state in an Era of Globalization. Medicine, Conflict and Survival, 24, 201-218.

Sutherland C (2014) Political Discourse and Praxis in the Glasgow Church. Political Geography, 38, 23-32.

Sutherland C (2016) Theography and Postsecular Politics in the Geographies of Postchristendom Communities (Doctoral Thesis). University of Exeter. Available from http:// ore.exeter.ac.uk/repository/handle/10871/27782.

Sutherland C (2017) Theography: Subject, Theology, and Praxis in Geographies of Religion. Progress in Human Geography, 41(3), 321-337.

Sweeney J (2008) Revising Secularization Theory. In Ward G and Hoelzl M (eds) The New Visibility of Religion. London: Continuum, pp. 15-29.

Talvacchia KT, Pettinger MF, and Larrimore M (eds) (2014) Queer Christianities: Lived Religion in Transgressive Forms. New York, NY: New York University Press.

Tarlo E (2007) Hijab in London: Metamorphosis, Resonance and Effects. Journal of Material Culture, 12, 131-156.

Taubes J (2004) The Political Theology of Saint Paul. Stanford, CA: Stanford University Press.

Taylor B (2010) Dark Green Religion Nature: Spirituality and the Planetary Future. Berkeley and London: University of California Press.

Taylor C (2002) Varieties of Religion Today. Cambridge, MA: Harvard University Press.

Taylor C (2007) A Secular Age. Cambridge, MA: Harvard University Press.

Taylor C (2010) The Meaning of Secularism. Hedgehog Review, Fall, 23-34.

Taylor C (2011) Why We Need a Radical Redefinition of Secularism. In Butler J, Habermas J, Taylor C, West C, edited by Mendieta E and VanAntwerpen J, afterword by Calhoun C. The Power of Religion in the Public Sphere. New York: Columbia University Press, pp. 34-59.

Taylor MC (1987) Erring: A Postmodern A/theology. Chicago, IL: University of Chicago Press.

Tharoor I (2016) ISIS Calls for Holy War Find an Echo in Pro-Trump Movement. Washington Post 16 November 2016. Available from www.washingtonpost.com/news/ worldviews/wp/2016/11/16/isis-wants-to-fight-a-holy-war-so-do-some-trumpsupporters/?utm_term $=.43$ b3b2b7eb3e (last accessed 20/07/18).

The Holy Bible: English Standard Version (2001) Wheaton, IL: Crossway.

Thomas S (2013) Re-engaging with the Margins: The Salvation Army 614 UK Network and Incarnational Praxis. In Cloke P, Beaumont $\mathrm{J}$ and Williams W (eds) Working 


\section{Bibliography}

Faith: Faith-based Organisations and Urban Social Justice. Milton Keynes: Paternoster Press, pp. 66-84.

Thrift N (1996) Spatial Formations. London: Sage.

Tosi S and Vitale T (2009) Explaining How Political Culture Changes: Catholic Activism and the Secular Left in Italian Peace Movements. Social Movement Studies: Journal of Social, Cultural and Political Protest, 8(2), 131-147.

Tse JKH (2014) Grounded Theologies: 'Religion' and the 'Secular' in Human Geography. Progress in Human Geography, 38, 201-220.

Tse JKH (2015) Under the Umbrella: Grounded Christian Theologies and Democratic Working Alliances in Hong Kong. Review of Religion and Chinese Society, 2(1), 109-142.

Tse JKH and Tan J (ed.) (2016) Theological Reflections on the Hong Kong Umbrella Movement. New York: Palgrave.

Turner V (ed.) (1969) Liminality and Communitas. The Ritual Process: Structure and Anti-Structure. Chicago: Aldine Publishing Company, pp. 358-374.

Tyler I (2017) Revolting Subjects: Social Abjection and Resistance in Neoliberal Britain. London: Zed Books.

Valentine G (2008) Living with Difference: Reflections on Geographies of Encounter. Progress in Human Geography, 32(3), 323-337.

Valentine G and Sadgrove J (2012) Lived Difference: A Narrative Account of Spatiotemporal Processes of Social Differentiation. Environment and Planning A, 44, 2049-2063.

Valentine G and Waite L (2011) Negotiating Difference through Everyday Encounters: The Case of Sexual Orientation and Religion and Belief. Antipode, 44, 474-492.

Valverde M (1998) Diseases of the Will: Alcohol and the Dilemma of Freedom. Cambridge: Cambridge University Press.

Van Steenwyk M (2013) The Unkingdom of God: Embracing the Subversive Power of Repentance. Downers Grove, IL: InterVarsity Press.

Vasiliki R (2016) The Politics of Postsecular Feminism. Theory, Culture and Society, 33, $103-123$.

Vattimo G (2002) After Christianity. New York: Columbia University Press.

Vattimo G (2003) After Onto-theology: Philosophy Between Science and Religion. In Wrathall M (ed.) Religion After Metaphysics. Cambridge: Cambridge University Press, pp. 29-36.

Vattimo G (2007) Towards a Nonreligious Christianity. In Caputo J and Vattimo G (eds) After the Death of God. New York: Columbia University Press, pp. 27-46.

Vattimo G (2009) Not Being God: A Collaborative Autobiography. New York: Columbia University Press.

Vincett G (2013) 'There's Just No Space for Me There': Christian Feminists in the UK and the Performance of Space and Religion. In Hopkins P, Kong L, and Olson E (eds) Religion and Place: Landscape, Politics and Piety. New York, NY: Springer, pp. 167-184.

Voinea A (2014) The Co-operatives Acting as Agents for Peace. Cooperative News 13 August 2014. Available from www.thenews.coop/88497/topic/development/the-cooperatives-acting-as-agents-for-peace/ (last accessed 27/07/18).

Volf M (1996) Exclusion and Embrace: A Theological Exploration of Identity, Otherness and Reconciliation. Nashville, TN: Abingdon Press.

Vrasti W (2009) How to use Affective Competencies in Late Capitalism. Paper presented in British International Studies Association Conference, University of Leicester, December 2009. Available from www.bisa.ac.uk/index.php?option=com_bisa\&task=download paper\&no_html=1\&passed_paper_id=29 (last accessed 20/07/18). 
Walker P (2001) Pulling the Devil's Kingdom Down: The Salvation Army in Victorian Britain. London: University of California Press.

Walters W (2008) Acts of Demonstration: Mapping the Territory of (Non-)Citizenship. In Isin EF and Nielsen GM (eds) Acts of Citizenship. London: Zed Books, pp. 182-206.

Ward G (2000) Cities of God. London: Routledge.

Ward G (2005) Cultural Transformation and Religious Practice. Cambridge: Cambridge University Press.

Ward G (2009) The Politics of Discipleship: Becoming Postmaterial Citizens. Grand Rapids, MI: Baker Academic.

Ward G (2014) The Myth of Secularism. Telos, 167, 162-179.

Washington Post (2017) Deconstructing the symbols and slogans spotted in Charlottesville. Washington Post 18 August 2017. Available from www.washingtonpost.com/ graphics/2017/local/charlottesville-videos/?utm_term=.c7ca4f3bf56b (last accessed 20/07/18).

Watson J (2013) Post-secular Schooling: Freedom Through Faith or Diversity in Community. Cambridge Journal of Education, 43(2), 147-162.

Weber M (1976) The Protestant Ethic and the Spirit of Capitalism. London: Allen and Unwin, 2nd Edn.

White M (2016) The End of Protest: A New Playbook for Revolution. Toronto: Penguin Random House.

White M (2018) Micah White's Thought Bubble: Junk Thought. Available from www. micahwhite.com/micah-whites-though-bubble/ (last accessed 16/05/18).

Whitehead A, Perry S, and Baker J (2018) Make America Christian Again: Christian Nationalism and Voting for Donald Trump in the 2016 Presidential Election. Sociology of Religion, 79(2), 147-171.

Wickström L and Illman R (2015) Environmentalism as a Trend in Post-Secular Society. In Nynäs P, Lassander M, and Utrianinen T (eds) Post-Secular Society. New Brunswick: Transaction Publishers, pp. 217-238.

Wilford J (2010) Sacred Archipelagos: Geographies of Secularization. Progress in Human Geography, 34, 328-348.

Williams A (2013) Practical Theology and Christian Responses to Drug Use. In Cloke P, Beaumont J, and Williams A (eds) Working Faith: Faith-based Organizations and Urban Social Justice. Milton Keynes: Paternoster Press, pp. 47-65.

Williams A (2015) Postsecular Geographies: Theo-ethics, Rapprochement and Neoliberal Governance in a Faith-based Drug Programme. Transactions, Institute of British Geographers, 40, 192-208.

Williams A (2017) Residential Ethnography, Mixed Loyalties, and Religious Power: Ethical Dilemmas in Faith-based Addiction Treatment. Social \& Cultural Geography, 18(7), 1016-1038.

Williams A, Cloke P, May J, and Goodwin M (2016) Contested Space: The Contradictory Political Dynamics of Food Banking in the UK. Environment and Planning A, 48(11), 2291-2316.

Williams A, Cloke P, and Thomas S (2012) Co-constituting Neoliberalism: Faith-based Organisations, Co-option, and Resistance in the UK. Environment and Planning A, 44(6), 1479-1501.

Williams A, May J, Cloke P, and Cherry L (forthcoming) Feeding Austerity? Ethical Ambiguity and Political Possibilities in UK Foodbanks. Oxford: Wiley-Blackwell.

Williams DS (2013) Sisters in the Wilderness: The Challenge of Womanist God-Talk. New York, NY: Orbis Books. 


\section{Bibliography}

Williams P (2015) Everyday Peace? Politics, Citizenship and Muslim Lives in India. Oxford: Wiley-Blackwell.

Willis AC (2017) Notes Toward a Dissident Theo-Politics. Political Theology, 18(4), 290-308.

Wilson E (2014) Theorizing Religion as Politics in Postsecular International Relations. Politics, Religion \& Ideology, 15(3), 347-365.

Wilson HF (2014) Multicultural Learning: Parent Encounters with Difference in a Birmingham Primary School. Transactions of the Institute of British Geographers, 39(1), 102-114.

Wilson J and Swyngedouw E (2014) Seeds of Dystopia: Post-politics and the Return of the Political. In Wilson J and Swyngedouw E (eds) The Post-Political and its Discontents. Edinburgh: Edinburgh University Press, pp. 1-24.

Wilton R and DeVerteuil G (2006) Spaces of Sobriety/Sites of Power: Examining Social Model Alcohol Recovery Programs as Therapeutic Landscapes. Social Science and Medicine, 63, 649-661.

Winter E (2017) An Activist Religiosity? Exploring Christian Support for the Occupy Movement. Journal of Contemporary Religion, 32(1), 51-66.

Wolterstorff N (2007) The Paradoxical Role of Coercion in the Theory of Political Liberalism. Journal of Law, Philosophy and Culture, 1, 101-125.

Woodhead L (2012) Introduction. In Woodhead L and Catto R (eds) Religion and Change in Modern Britain. London: Routledge, pp. 1-33.

Woodward K (2011) Affective life. In Del Casino Jr VJ, Thomas ME, and Cloke P (eds) A Companion to Social Geography. Oxford: Wiley-Blackwell, pp. 326-345.

Yates GJ and Silverman MJ (2016) Needs of Children Experiencing Homelessness who are Living in Shelters: A Qualitative Investigation of Perceptions of Care Workers to Inform Music Therapy Clinical Practice. Voices: A World Forum for Music Therapy, 16(3), 77-101.

Yeoh B (1996) Contesting Space in Colonial Singapore: Power Relations and the Urban Built Environment. Singapore: Singapore University Press.

Yoder J (1994) The Politics of Jesus. Grand Rapids: Eerdmans.

Yorgason E and della Dora V (2009) Geography, Religion, and Emerging Paradigms: Problematizing the Dialogue. Social \& Cultural Geography, 10(6), 629-637.

Young I (2004) Responsibility and Global Labor Justice. Journal of Political Philosophy, $12,365-388$.

Yukich G (2013) One Family Under God: Immigration Politics and Progressive Religion in America. Oxford University Press: New York.

Zhe J (2011) Buddhism in the Reform Era: A Secularized Revival? In Chau A (ed.) Religion in Contemporary China: Revitalization and Innovation. London and New York: Routledge.

Zimmerman Y (2011) Christianity and Human Trafficking. Religion Compass, 5(10), $567-578$.

Žižek S (2000) The Fragile Absolute: Or Why is the Christian Legacy Worth Fighting For? London: Verso.

Žižek S (2001) On Belief. London: Routledge.

Žižek S (2004) Plea for Ethical Violence. Talk given to The European Graduate School. Zürich: EGS.

Žižek S (2011) Living in the End Times. London: Verso.

Žižek S (2017) The Courage of Hopelessness: Chronicles of a Year of Acting Dangerously. London: Allen Lane. 